\title{
дискУСії
}

\section{В. КОБОЛЕВ}

Институт геофизики им. С. И. Субботина НАН Украины, пр. Палладина, 32, Киев, Україна, 03142, тел. +38(044)4242152, эл. почта kobol@igph.kiev.ua

\section{ЗЕМЛЯ: ВИРТУАЛЬНОСТЬ ТЕКТОНИКИ ПЛИТ, КОНФОРМНОСТЬ ФИКСИЗМА И МОБИЛИЗМА}

https://doi.org/10.23939/jgd2017.02.119

Цель. Необходимость пересмотра взглядов на тектоническую эволюцию Земли вызвана неудовлетворенностью современной ее парадигмой - тектоникой литосферных плит. Целью настоящей статьи является здоровый критический анализ фундаментальных принципиальных дискуссионных положений концепции тектоники плит и гипотезы горячих поясов Земли. Методика. Анализ сущности гипотезы горячих поясов Земли и концепции тектоники плит, основных достоинств и недостатков, определяющих их возможности. Хронологический анализ и корреляция геологических структур Земли в связи с пространственным расположением их пересекающих палеомагнитных экваторов, отображающих соответствующие геотектонические эпизоды и катастрофические события в эволюции Земли. Результаты. Показана несостоятельность базисной динамической предпосылки тектоники литосферных плит - мантийной конвекции - из-за множественности (неустойчивости) результатов ее решения. В качестве альтернативы рассматривается миграция твердой оболочки планеты по жидкофазной кровле внешнего ядра - нижняя астеносфера - под воздействием ротационно-гравитационного механизма. При этом вне обсуждения остается конвекционное перемешивание мантийного вещества и производные от него субдукционно-обдукционные перемещения литосферы. Ротационно-гравитационный режим Земли представляется основным механизмом структурного преобразования тектоносферы, который привел к формированию на максимумах разновозрастных и разнонаправленных антиформ экваториальных вздутий планеты ротационных рифтогенов. Научная новизна. По степени самодостаточности предлагаемая гипотеза горячих поясов Земли представляется в качестве недостающего звена между антиподальными геологическими мировоззрениями: фиксизма, чьи сложившиеся научные каноны остались неприкосновенными, и мобилизма в новой его транскрипции на основе динамического ротационно-гравитационного механизма и сопровождающего глубинного субъядерного магматизма. Практическая значимость. Пересечение разновозрастных структур палеоэкваторами обусловило формирование в различных регионах мира рифтогенных узлов и их аномальных объединений, в пределах которых известны крупнейшие промышленные скопления углеводородов. Анализ рифтогенных узлов, как путей миграции глубинных флюидов и зон разгрузки глубинной энергии, позволит нестандартно подойти к разработке новой стратегии поиска углеводородного сырья.

Ключевые слова: тектоника плит; горячие пояса Земли; ротационно-гравитационный механизм; рифтогены; глубинный субъядерный магматизм.

\section{Введение}

Прошло десять лет после выхода в свет монографии "Горячие пояса Земли" [Оровецкий, Коболев, 2006], которая явилась логическим продолжением изучения Ю. П. Оровецким явления мантийного диапиризма [Оровецкий, 1990; Orovetsky, 1999]. По своей сути гипотеза горячих поясов Земли (ГПЗ) развивает учение о механизме рифтообразования, рассматривая его под несколько необычным углом зрения. Если ранее Ю. П. Оровецким анализировался преимущественно кинематический аспект явления, а из динамических эксплуатировался лишь принцип гравитационной неустойчивости вещества, то в гипотезе ГПЗ предпринята попытка увязки рифтогенеза с динамикой ротационного режима планеты. Наибольший тектонический эффект при этом связывается нами с полярным уплощением геоида и формированием на максимумах палеоэкваториальных вздутий проницаемых трансмантийных зон для субъядерных магматических расплавов в виде радиально направленных приэкваториальных каналов малой вязкости. При этом, миграцию экваториального вздутия и, естественно, значительные изменения напряженного состояния тектоносферы обуславливает полярный дрейф, представляющий собой перемещение оболочки Земли по сплошной поверхности слабовязкого субъядра относительно астрономической оси вращения. Таким образом, оставаясь в рамках методологии мобилизма, мы перенесли акцент с верхней астеносферы Земли на нижнюю - жидкое внешнее ядро, т.е. в перемещении принимает участие вся оболочка Земли в целом в связи с динамикой ротационного режима планеты. 
В целом, горячие пояса Земли представляют собой векторные тектонические структуры растяжения, приуроченные к максимумам еe разновозрастных экваториальных вздутий.

Надо честно признать, что предложенная нами гипотеза ГПЗ не нашла адекватного резонанса и не была воспринята геологической общественностью. Многие ее положения были подвержены острой критике. Отрицательная оценка работы со стороны известного палеомагнитолога Д. М. Печерского была для нас ожидаемой [Печерский, 2008]. Несмотря на ее резкий характер, обусловленный острым синдромом плитнотектонического доктринерства [Оровецкий, Коболев, 2008], отдельные критические замечания заслуживают внимания.

\section{Цель}

Необходимость пересмотра взглядов на тектоническую эволюцию Земли вызвана неудовлетворенностью современной ее парадигмой - тектоникой литосферных плит. Ученые имеют право на свободу в выборе точки зрения, поэтому вполне закономерным и неизбежным является тот факт, что известные противоречия между базисными положениями концепции тектоники плит (ТП) и экспериментальными данными продолжают обсуждаться и в настоящее время. При этом они вызывают серьезную озабоченность у одних специалистов [Павленкова, 2004; Pavlenkova, 2012, 2017; Тяпкин, 2012, 2013; Гордиенко, 2012, 2013; Storetvedt, 2014, 2015 и др.] и, напротив, полное удовлетворение у других, не обращающих внимания на критические противоречащие данные [Печерский, 2008; Добрецов и др., 2001; Добрецов, 2010; Трубицын, 2005, 2012; Хазан, 2014; Белевцев, Блажко, Терещенко, 2016 и др.]. В частности, среди публикаций последних лет специального международного журнала "New Concepts in Global Tectonics" обращают на себя внимание статьи двух авторов, представляющие, на мой взгляд, существенный интерес, как с точки зрения нерешенных проблем структуры и динамики тектоносферы [Pavlenkova, 2012; Storetvedt, 2014], так и историко-хронологического анализа становления концепции ТП [Storetvedt, 2015].

В первом случае Н. И. Павленковой представлены экспериментальные данные основных особенностей структуры тектоносферы, которые не находят объяснения в рамках концепции ТП. Указанным автором предложена новая геодинамическая флюидно-ротационная концепция, в которой предпринята попытка объединить все известные сведения о строении верхних сфер Земли в единую систему их формирования с общими источниками энергии [Павленкова, 2004; Pavlenkova, 2012]. К. Сторедведт, автор известной теории вращения континентов, блестяще обосновал модернизацию в 1960-х годах гипотезы дрейфа Вегенера с помощью палеомагнитологии и механизма ТП, а также последующее ее триумфальное шествие на основе человеческих факторов [Storetvedt, 2015]. Главным выводом вышеназванных публикаций является тот факт, что концепция ТП не может быть использована в качестве основного принципа глобальной геодинамики, поэтому для объяснения наблюдаемых геологических и геофизических данных должны быть разработаны другие модели.

Систематический обзор обширной литературы по этой проблеме и разных точек зрения не является предметом рассмотрения настоящей статьи, а приведенные публикации являются лишь одними из многочисленных и показательных примеров современной дискуссии. К сожалению, следует отметить, что многие авторы теоретических работ, сторонники концепции ТП, не затрудняют себя анализом нерешенных проблем структуры и динамики тектоносферы, а также не рассматривают альтернативные модели.

В настоящей статье основной акцент сделан на решении спорных вопросов теоретической геотектоники, касающихся, прежде всего, механизма вертикальных и горизонтальных перемещений и не находящих адекватного объяснения в рамках господствующей парадигмы - концепции ТП. Целью настоящей статьи является здоровый критический сравнительный анализ фундаментальных принципиальных дискуссионных положений ТП и гипотезы ГПЗ.

\section{Методика}

Рассмотрение общих вопросов развития Земли требует во всех случаях инвариантности реконструкции временного хода этого развития. И сколько бы ни увеличивался багаж наших знаний о геодинамических особенностях изучаемого объекта, геоисторизм при изучении эволюции всегда остается во главе угла. Этому условию из всех направлений геофизических исследований наиболее полно соответствует палеомагнитология в виде конечного ее продукта - координат древних, различного возраста магнитных полюсов. Поэтому, как и в концепции ТП, в качестве основной теоретической предпосылки гипотезы ГПЗ используется широко известный в палеомагнитологии научный постулат о пространственновременном перемещении древних магнитных полюсов (рис. 1), траектории которых соответствуют пространственному местоположению географического полюса.

Однако, в отличие от концепции ТП, которая анализирует миграцию палеомагнитных полюсов, в гипотезе ГПЗ предпринята попытка изучения пространственного расположения палеомагнитных экваторов, построенных по известным полярным координатам. Опыт оказался, на удивление, результативным. Палеомагнитные полюса, а с ними и палеомагнитные экваторы, 
перемещаясь относительно стационарного положения земной оси, пересекают большее число геологических структур, которые отображают соответствующие геотектонические эпизоды и поддаются, тем самым хронологическим анализу и корреляции. Такая трансформация методологии палеомагнетизма привела к большей геоинформативности, ибо вместо единокоординатного полюса, хронологическому изучению и корреляции стали доступны многие геотектонические структуры, пересекаемые плоскостью соответствующего экватора.

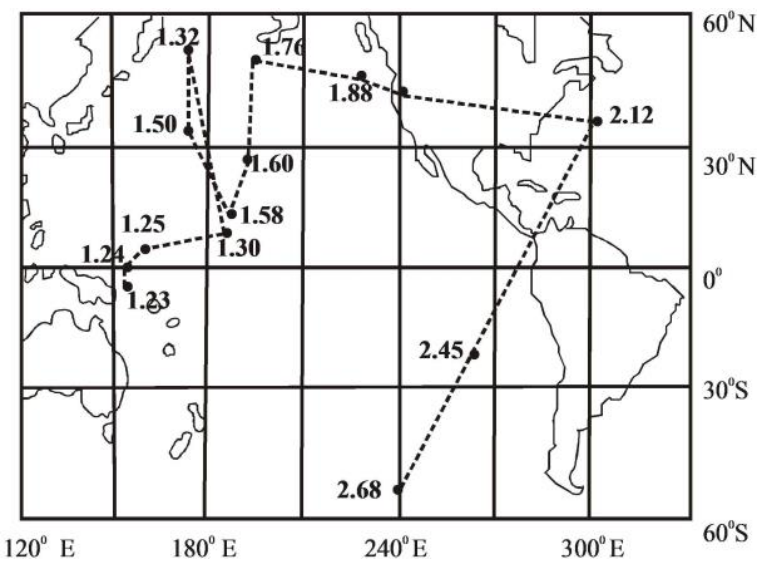

Рис. 1. Миграция древнего магнитного полюса Земли в протерозое (по [Михайлова и др., 1994]). Оцифровка - возраст, млрд. лет

Fig. 1. Geomagnetic pole path in the Proterozoic [Michailova et al., 1994]. Age is numbered in Ma

Таким образом, в нашем случае избрано альтернативное направление исследований: изучается пространственная дисперсия пространственного расположения палеомагнитных экваторов, автоматически и функционально связанных с древними магнитными полюсами.

Миграция палеомагнитных полюсов в орто- и диагональных направлениях и когерентных с ними по возрасту экваторов осуществляется при помощи ротационно-гравитационного механизма. При этом если долготные перемещения обязаны восточному вращению планеты, то широтные связываются с постоянно действующей и потому тектонически эффективной, силой Этвеша.

\section{Результаты \\ Фиксизм и мобилизм}

В настоящее время существует достаточно много гипотез и концепций структурно-тектонической эволюции верхней оболочки Земли. В целом, по принципу примата вертикальных или горизонтальных перемещений их можно условно отнести соответственно к мировоззрениям фиксизма и мобилизма.
$\mathrm{B}$ первой половине $\mathrm{XX}$ в. получила широкое развитие и практически всеобее признание концепция геосинклиналей и соответствующая классическая форма фиксистского мировоззрения. Согласно этой концепции, полный цикл развития верхней оболочки Земли происходил в рамках строго фиксированного пространства и без значительных горизонтальных перемещений. Основным ее достоинством является минимальное использование гипотетических предположений. Однако ее классические представления, базирующиеся на статической совокупности закономерностей, установленных путем экспериментального изучения реальных структур континентальной оболочки Земли, во многом исчерпали свой ресурс. Прежде всего, это касается отсутствия источника сил, способного объяснить возникновение и развитие структур земной коры, а также источника энергии, поддерживающего эти силы [Тяпкин, 2012, 2013].

Продуктивной попыткой восполнить этот пробел концепции геосинклиналей следует считать Новую ротационную гипотезу структурообразования в земной коре К. Ф. Тяпкина, основанную на использовании ротационного режима Земли [Тяпкин, Довбнич, 2009; Тяпкин, 2012, 2013]. Таким образом, концепция геосинклиналей получила количественное обоснование причин пространственного распределения $30 \mathrm{H}$ растяжения и сжатия в тектоносфере Земли и их изменение во времени, а также позволила объяснить явления инверсии геосинклинальных структур.

В этом контексте полезна также адвекционнополиморфная гипотеза (АПГ), активно развиваемая B. В. Гордиенко в рамках концепции геосинклиналей [Гордиенко, 2012]. По мнению автора АПГ привнос разогретого легкого материала является результатом адвекции, которая связана с “квантами тектонического действия". Вместе с тем, ряд главных вопросов в АПГ остаются без ответа. Прежде всего, это касается причин возникновения адвекции. Если адвекция - это та же конвекция, но без возврата, то, что в этом случае первично? Активизация или конвекция (в нашем случае надо понимать адвекция)? И самый главный вопрос: где причина, а где следствие?

В отличие от концепции геосинклиналей и указанных выше ее производных гипотез, разработка новых мобилистских геодинамических вариантов осуществлялась не от природных объектов к теоретическим выводам, а от заранее заданных идей. Среди мобилистских гипотез и теорий наиболее популярной, широко известной и в настоящее время практически общепринятой парадигмой является плитотектоническая система взглядов на структурное развитие Земли. Тем не менее, несмотря на очевидные успехи концепции ТП, ее не следует возводить в ранг вечных и непогрешимых истин [Storetvedt, 2015]. 
Решающим толчком к разработке концепции ТП явились результаты большого объема геологогеофизических исследований в Мировом океане. Обнаружение срединно-океанических хребтов явилось отправной точкой к разработке последующих еe базисных положений: спрединг океанического дна и субдукция, конвекция в мантии и перемещение плит. Два последних положения, являющиеся принципиальными в определении реальности концепции ТП, остаются до сих пор не только не доказанными, но и остро дискуссионными [Павленкова, 2004, Pavlenkova, 2012, 2017; Тяпкин, 2012, 2013; Гордиенко, 2012, 2014; Хазан, 2014; Storetvedt, 2015 и др.].

Для объяснения причин движения литосферных плит привлекаются конвективные потоки вещества в мантии [Добрецов и др., 2001; Добрецов, 2010; Трубицын, 2005, 2012 и др.]. Обращение к конвекции неслучайно, а закономерно обусловленное поиском источника энергии, приводящего в действие основной динамический механизм концепции ТП. Ее сторонники использовали широко известное в физике явление конвективного перемешивания, как следствия предполагаемого, преимущественно радиоактивного, разогрева среды. Однако классическая конвекция может осуществляться лишь в газо- и жидкофазной среде. В данном случае этому препятствует исключительно высокая вязкость вещества мантии Земли, что основывается на неоспоримых сейсмологических измерениях ее скоростных параметров. Для выхода из создавшегося критического положения вводится итоговый решающий фактор в виде длительности геологического времени. Движения, возникающие при перемешивании мантийного вещества, возводятся в ранг основной причины миграции литосферных плит.

Большинство исследователей склоняются к модели крупномасштабной конвекции мантийного вещества в виде гигантских замкнутых ячей. Существуют мнения о многоступенчатой конвекции, а также более локальной - двухступенчатой: в нижней мантии - плотностная конвекция за счет дифференциации ее вещества по объемному весу; в верхней - своеобразная тепловая, квазипериодического характера, за счет поступающей из нижней мантии тепловой энергии. Разработаны также трехмерные численные модели мантийной конвекции с плавающими континентами [Трубицын, 2005] и мелкочешуйчатой верхнемантийной конвекции [Добрецов, 2010].

Bce упомянутые сложные механизмы в методологическом плане являются результатом теоретического численного моделирования. Для приближения к адекватному их описанию вводятся граничные линеаризованные, более легко поддающиеся исследованию условия, которые изза неполноты знаний о конкретных условиях физического процесса подчас коренным образом искажают основной смысл явления, а их результаты потом оказывают такое же влияние на дальнейшие построения. Следует также подчеркнуть, что установленный градиент температуры солидуса вещества мантии практически совпадает с его адиабатой [Магницкий, 2006], что говорит о маловероятности существования тепловой конвекции. К тому же наличие слоистости (оболочек) Земли, связанной с изменением состава вещества от слоя к слою, делает такие потоки просто невозможными. Факт существования корней континентов также указывает на отсутствие значимых подвижек литосферных плит по латерали [Pavlenkova, 2012, 2017]. Принимая во внимание изложенное, мы воспринимаем множественность мнений о наличии конвекции вещества в мантии в качестве нерешенной, а может даже и неадекватно поставленной задачи.

Освобождаясь, таким образом, от крупномасштабной мантийной конвекции, мы, тем самым, оставляем за пределами обсуждения производный от нее субдукционно-обдукционный механизм перемещения литосферы, который, на наш взгляд, представляет собой скорее артефакт, нежели предмет конструктивной научной проблемы.

Вместе с тем, нельзя отрицать существование конвективного тепломассопереноса в виде локальных, различного рода магматогенов, для которых существенным является восходящий поток вещества [Грачев, 2000]. Эти магматогены, объединенные общим термином “плюм-тектоника”, играют роль теплового клапана, при помощи которого Земля отводит излишнее количество эндогенного тепла за свои пределы [Maryama, 1994].

В проблеме мантийных плюмов активно обсуждается два вопроса: уровень генерации плюмов и механизм перемещения вещества плюма из области генерации к поверхности [Анфилогов, Хачай, 2007]. Разные авторы связывают различные уровни мантии, вплоть до внешнего ядра, где могут зарождаться (генерироваться) плюмы. Главным критерием, определяющим место зарождения плюма, является возможность появления на данном уровне в определенный момент времени источника тепловой или механической энергии, которая инициирует образование вертикального перемещения вещества. При этом подчеркивается, что в верхней мантии автономные источники, мощность которых достаточна для образования плюма, отсутствуют [Грачев, 2000].

Отклонения амплитуды от сферической формы верхней границы слоя "D”, достигающие 20 км [Добрецов и др., 2001], могут свидетельствовать о наличии на этой границе периодически возникающих локальных вариаций тепловой энергии за счет частичного плавления [Lay, 2005]. В результате частичного плавления или твердофазного перехода, сопровождающегося увели- 
чением объема в области фазового перехода, возникает избыточное давление. Давление на границе ядро - мантия $1,35 \times 10^{5}$ МПа (135 ГПа). Увеличение при фазовом переходе объема на $1 \%$ приведет к локальному увеличению давления на $1350 \mathrm{MПа} \mathrm{и} \mathrm{накоплению} \mathrm{в} \mathrm{этой} \mathrm{области}$ избыточной потенциальной энергии [Анфилогов, Хачай, 2007]. Выполненные указанными авторами расчеты позволили сделать вывод, что порция энергии, необходимая для генерации плюмов выделяется на границе ядро-мантия. Так как слой D" находится в контакте с жидким ядром, то возникающий в нем импульс избыточного давления достаточно быстро релаксируется путем перераспределения вещества в ядре. Поэтому движение плюмов носит импульсный характер и поднятия над плюмами никогда не достигают той величины, которая должна быть, если бы основание плюма было бы жестким. По этой же причине плюмовые тектонические потоки неустойчивы во времени и, возникнув в одном месте, поток может оборваться в его основании, чтобы через некоторое время возникнуть в другом месте. В результате в мантии методами сейсмотомографии фиксируются многочисленные термические неоднородности, “подвешенные" на разной глубине от поверхности.

Таким образом, вертикальная транспортировка магматического расплава в оболочку Земли в объемах мультимагматогенов мантийных плюмов, в полном соответствии с всеобщим законом сохранения энергии, вызывает эквивалентное недостающее его количество в субъядре. В гравитационном поле указанный дефицит возмещается путем компенсационного погружения кровли с формированием соответствующих мультиотрицательных морфоструктур. К этому процессу, повидимому, можно отнести увеличение глубин в Мировом океане, а также установленное пятикратное превышение погружений над воздыманиями по поверхностям геоида и раздела М [Оровецкий, Коболев, 2006].

\section{Ротационно-гравитационный механизм}

Главная гносеологическая ошибка концепции ТП при ее создании заключена в изоляции Земли от окружающей космической обстановки, непременной и активной составляющей которой она является. В итоге искусственно отсеченным оказался динамический ротационный эффект пожалуй, единственный, который логически просто может обеспечить эндогенную энергетику планеты по схеме: ротация - сила тяжести, тяжесть давление, давление - фрикционная температура. И только в конце этой генерализованной цепи событий, в области сверхвысоких термодинамических режимов будущего внешнего ядра возник второй, не менее активный фактор развития Земли. Им оказалась жидкая фаза изначального планетезимального вещества в виде магма- тического расплава, аутентичного селективному составу аккреционного субстрата. Этот тезис автоматически определяет внутреннее ядро Земли как твердофазную, тугоплавкую при высоких давлениях матрицу, а модель аккреции - как гетерогенную, в которой слагающие ее планетезимали имели индивидуальный вещественный состав, в том числе включая и радиоактивные теплогенераторы. Современные модельные представления о составе и строении ядра Земли, границы ядро - мантия и их влиянии на массоперенос и глобальные циклы вещества с позиции экспериментальных исследований при высоких давлениях и температурах наиболее полно приведены в обобщающей монографии [Литасов, Шацкий, 2016].

При изучении тектонических процессов тектогенеза главной задачей является определение энергетических источников, способных поддерживать эти процессы. Ранее считалось, что наиболее мощным энергетическим источником является кинетическая энергия осевого вращения Земли, т.е. любые изменения в скорости вращения планеты должны приводить к существенным тектоническим последствиям. Таким образом, изменения скорости вращения должны создавать напряжения в оболочке Земли, превосходящие предел ее упругости и вызывающие пластические и необратимые деформации [Тяпкин, 2013].

В этом отношении существенный интерес представляют расчеты напряжений в тектоносфере, выполненные М. М. Довбничем с привлечением задач теоретической механики о деформациях вращающейся Земли вследствие изменения еe ротационного режима [Тяпкин, Довбнич, 2009]. Оказалось, что количественно охарактеризованные максимальные значения напряжений (10 нием угловой скорости вращения Земли, не могут оказывать существенного влияния на формирование тектонических структур в земной коре. Однако рассчитанные ротационные напряжения, обусловленные изменением положения оси вращения Земли, достигают критических значений прочности пород тектоносферы Земли (10 Таким образом, предлагаемый ротационногравитационный механизм перемещения всей твердой оболочки Земли, который приводит к существенному изменению положения оси ее вращения, представляется оптимальным для истолкования природы архитектонических сооружений Земли.

Вместе с тем следует подчеркнуть, что модели, способной объяснить механизм глобального процесса и все закономерности перемещения оси вращения Земли, в настоящее время не существует [Авсюк, Суворова, 2007]. Авторы логично задают вопрос, а не связан ли процесс изменения положения оси вращения в теле Земли с перемещением внутреннего ядра. Попробуем разобраться. 
Горизонтальные движения мы связываем с изменением главного момента инерции Земли: $\mathrm{J}=\mathrm{mR}^{2}$ (m - масса, $\mathrm{R}$ - радиус) и производными от него флуктуациями угловой скорости вращения. Раскрывая физическую сущность приведенного уравнения, подчеркнем, что единственной переменной величиной, обеспечивающей искомый эффект, является радиус Земли. Его изменение, скорее всего, связано с фазовыми превращениями первого рода (плавление и кристаллизация), иначе - с магмогенезом. А поскольку масштабы магмогенеза в виде мультимагматогенов мантийных плюмов согласно современным данным сейсмической томографии достигают в отдельных случаях трансмантийных, до внешнего ядра, глубин, это заключение представляется близким к реальности. При плавлении локальный радиус Земли увеличивается, кристаллизация же, наоборот, приводит к его уменьшению. Думается, что именно с этими трансформациями, согласно принципу главного момента инерции, испытывает соответствующие превращения и угловая скорость Земли $(\omega)$.

Согласно сейсмологическим моделям, наша планета имеет две астеносферы. Верхняя подстилает литосферу, пространственно дискретна и, несмотря на это, по мнению сторонников концепции ТП, служит ложем для перемещения плит. Нижняя астеносфера представляет собой жидкий сферический слой Е (внешнее ядро, или субъядро, Земли) без каких-либо существенных нарушений по латерали и глубине. Поэтому при изменении скорости вращения Земли ее высокоплотностное внутреннее ядро инерционно продолжит свое вращение в упомянутом слабовязком сферическом слое Е. В случае ускорения $\omega$, вращение ядра будет отставать от перемещения оболочки Земли (западный дрейф); уменьшение же $\omega$, наоборот, вызовет ускоренное вращение ядра по сравнению с вращением оболочки (восточный дрейф). Иными словами, внешнее ядро в ротационном поле Земли обладает сферической симметрией, чем создаются оптимальные условия для латеральной миграции твердой оболочки путем “проскальзывания" ее по жидкофазной верхней границе слоя Е. Литосфера Земли на такие глубинные инерционные пертурбации, безусловно, будет реагировать соответствующими горизонтальными перемещениями относительно оси магнитного диполя, что непременно будет зафиксировано палеомагнитным методом. Для такой динамики, в отличие от представлений плитовой тектоники, снимаются ограничения в виде пространственной дискретности верхней астеносферы.

Вместе с перемещающейся оболочкой относительно магнитного диполя мигрируют и палеомагнитные полюса планеты, вернее, уже не сами полюса, а точки былого их стояния, зафиксированные палеомагнитным опробованием и спроецированные на земную поверхность при помощи векторов остаточного намагничивания соответствующих пород.

Таким образом, миграция палеомагнитных полюсов связывается нами не с движениями литосферных плит за счет конвекционного перемешивания мантийного вещества, а с ротационногравитационным механизмом перемещения всей ее твердой оболочки, который приводится в действие спонтанным появлением в высоких широтах Земли крупной гравитационной неоднородности (магматогена). Миграция неоднородности также осуществляется в орто- и диагональных направлениях. Если ее широтное перемещение является инерционным следствием восточно-направленного вращения Земли, то передвижение по меридиану - проявлением силы Этвеша, тектонический эффект которой значимый во времени. Результирующие этой пары сил порождают широкий спектр диагональных перемещений, которые в конечном итоге обуславливают регматическую тектонику планеты. Находясь внутри оболочки Земли, гравитационная неоднородность принудительно разворачивает ее в любом вызванном направлении по жидкофазной границе кровли внешнего ядра. Перечисленные факторы сопровождаются непременной миграцией древних магнитных полюсов, вернее точек былого их стояния, на мобильной сфере Земли.

В соответствии с флюидно-ротационной гипотезой [Pavlenkova, 2012], перемещение континентов представляется также результатом вращения мантии по отношению к жидкому ядру, так как только такие движения были в состоянии не нарушить установленные закономерности структуры тектоносферы.

Вторым не менее важным аспектом ротационного режима Земли является тектонический эффект, обусловленный полярным уплощением геоида и формированием в области максимальных центробежных ускорений силы тяжести - палеоэкваториальных вздутий - проницаемых трансмантийных зон для субъядерных магматических расплавов.

Согласно закону сохранения количества движения, выраженному произведением массы частицы на ее угловую скорость и радиус вращения, при изменении скорости вращения Земли каждая выплавка мантийного субстрата будет стремиться сохранить свой момент количества движения. При замедлении вращения планеты уменьшается линейная скорость частицы при неизменной ее массе, Учитывая то обстоятельство, что условие сохранения величины момента импульса возможно лишь за счет увеличения радиуса, т. е. каждая частица, образующаяся при выплавке мантийного субстрата, будет стремиться перейти на больший радиус, т. е. смещаться в сторону экватора [Филатьев, 2007].

Современная экваториальная область отличается наибольшим на Земле центробежным ускорением 
силы тяжести ( $\mathrm{q}_{\Perp б}=-3,392$ Гал), которое ответственно в том числе и за динамику эндогенных процессов. Здесь статистически установлено закономерное увеличение в сторону экватора количества вулканов и очагов землетрясений со значительными магнитудами [Виноградов, Кудрявцев, 1987]. Наличие в приэкваториальных широтах гигантских магматогенов не только подчеркивает существование там растягивающих напряжений рифтинга, но также указывает на сопровождающую, радиальную по глубине, магматически проницаемую область, глубина заложения которой достигает внешнего ядра Земли. Сейсмотомографическими исследованиями под ротационными рифтогенами на границе с внешним ядром обнаружены ультранизкоскоростные области, что считается признаком зарождения и присутствия там мантийных плюмов ([Larson, Olson, 1991] и др.).

Плавление в замкнутом объеме сопровождается автоклавным эффектом, что сказалось на возрастании внутреннего давления в жидком внешнем ядре. Таким способом в центральной части планеты осуществилась диалектика перехода динамической гравитационной энергии в кинетическую термореактивную. Несмотря на разную физическую природу, оба вида энергии оказались общефункциональными. Из сложившегося метастабильного состояния указанная система способна выйти только лишь в случае нарушения сплошности перекрывающей среды в виде тектонического разрыва, представляющего собой канал малой вязкости. Место нарушения определяется экваториальной областью планеты, где вращением Земли создана радиальная по глубине зона наибольших растягивающих напряжений ротационного рифтинга.

Вдоль экваториальной области, побуждаемый максимальным центробежным ускорением силы тяжести, высоким внутренним давлением и декомпрессионным увеличением объема устремляется расплав ее внешнего ядра. Эти факторы в комплексе создают длительный расклинивающий эффект и не дают возможности к “заплыванию” канала малой вязкости на глубине. Этим обеспечивается перманентность магматизма в виде мультимагматогенов мантийных плюмов. Как будет показано ниже, аналогичные древние экваториальные раздвиговые структуры представлены ротационными рифтогенами срединно-океанических хребтов. Таким образом, привлечение динамического ротационного эффекта Земли, которому в тектонике литосферных плит не нашлось места, позволило придти к непротиворечивому, как представляется, истолкованию природы срединно-океанических хребтов без привлечения для этого механизма конвекции мантийного вещества.

В результате представляется, что рифтообразующая роль не только современного, но также и древних экваторов Земли при формировании глубинных раздвигов планетарного масштаба не должна вызывать скептицизма.

\section{Горячие пояса Земли}

Использованные нами 51 палеомагнитный экватор, построенные по координатам соответствующих древних магнитных полюсов, образовали на стереографических проекциях две крупные разновозрастные группы. В более древнюю, субмеридионально ориентированную в современных низких широтах Земли, вошли 8 дофанерозойских и 31 палеозойский палеомагнитных экваторов. Они оказались в той или иной степени пространственно привязанными к георифтогеналям срединно-океанических хребтов, имеющим в современных низких широтах Земли такие же, близкие к меридиональному, простирания (рис. 2, 3). Более молодая - мезозойская группа оказалась представленной остальными 12-ю их аналогами, но ориентированными уже в субширотном направлении, близком к современной тектонически ослабленной и потенциально рифтогенной приэкваториальной области Земли (рис. 4).

Такая значительная, по величине и разная по возрасту, переориентировка палеомагнитных экваторов, установленная на статистически представительном материале, думается, не случайна. Обращает на себя внимание планетарный характер указанной перестройки: горизонтально перемещаются не отдельные плиты, а одновременно и целиком их ансамбли, что свидетельствует о более глубоком расположении поверхности перемещения, нежели это принято в концепции ТП.

Вторым важным обстоятельством является тот факт, что указанная грандиозная 90-градусная перестройка тектонического плана Земли на границе палеозоя и мезозоя одновременно привела ее оболочку к отклонению от стационарной направленности Солнечной радиации. Это вызвало производное пространственное перемещение климатических зон планеты, что сопровождалось наибольшим в истории Земли вымиранием живых организмов на границе пермского и триасового периодов, не успевших в столь короткий срок адаптироваться к резко изменившимся экологическим условиям.

По разным оценкам в это время примерно 90 процентов живых видов исчезло в море и на суше одновременно. Наиболее точная датировка этого катастрофического события приведена в статье международной группы ученых, опубликованной в журнале "Science" [Shen et all., 2011]. В результате исследований было установлено, что это событие произошло 252,28 миллиона лет назад, а весь процесс занял около 200 тысяч лет. Причиной такого планетарного масштаба катастрофы, по мнению этих исследователей, стала мощная вулканическая активность, а именно, излияние огромного объема магмы на поверхность через разломные зоны в земной коре без образования вулканов. В качестве примера подобного рода излияний приводятся известные сибирские траппы. 
Новые доказательства того, что сибирские траппы, которые сформировались на границе перми и триаса, могли стать причиной катастрофы приведены в работе [Grasby et al., 2011].

Указанными исследователями в породах, образовывавшихся непосредственно перед началом пермской катастрофы, были обнаружены микроскопические частицы, которые по массе и размеру напоминали частицы угля. Исследователи полагают, что такие частицы могли сформироваться во время извержения лавовых потоков сквозь сибирские угольные отложения. Легкие фрагменты угля могли подниматься в атмосферу на высоту до 20 километров и распространяться по планете за счет воздушных потоков. Когда угольные частицы, содержащие вкрапления тяжелых металлов, попали в океан, его воды стали токсичными для обитателей Земли.

Существует еще несколько популярных гипотез, объясняющих это грандиозное массовое вымирание живых организмов. В частности, в пользу вулканической гипотезы пермского вымирания высказано предположение, что во время извержений на сибирских траппах лава “впитала" триллионы тонн фтора, хлора и серы, которые, попав в атмосферу, могли разрушить озоновый слой [Shen et all., 2011].

Не останавливаясь на различных причинноследственных толкованиях, можно считать достаточно обоснованным тот факт, что массовое выми- рание и многочисленные одновременные извержения магматических потоков не просто совпали по времени, а были вызваны одной и той же причиной. А именно, глобальная тектоническая перестройка, которая сопровождалась общей регрессией Мирового океана и обострением эндогенных процессов в виде планетарного платобазальтового тектономагматизма, была вызвана перемещением древней и самой крупной на Земле Восточно-Тихоокеанской гравитационной неоднородности по поверхности слабовязкого субъядра Земли [Коболев, Оровецкий, 2006]. Таким образом, трансформация геомагнитного поля и усиление глобального магматизма в это время - эти два фактора непосредственно связаны с жидкофазным веществом субъядра и его гидродинамическими возмущениями.

\section{Обсуждение результатов}

Учитывая тектонически предопределяющую (рифтогенную) роль палеомагнитных экваторов, приходим к заключению о ротационной природе срединно-океанических хребтов. К этому нас побудила практическая соосность георифтогеналей с древними палеомагнитными экваторами, а также рекуррентность тектоники в их пределах возвращение молодых палеомагнитных экваторов (19), (20), (24), (25) и др. к своему изначальному (2), (3), (6) положению (см. рис. 2, 3).

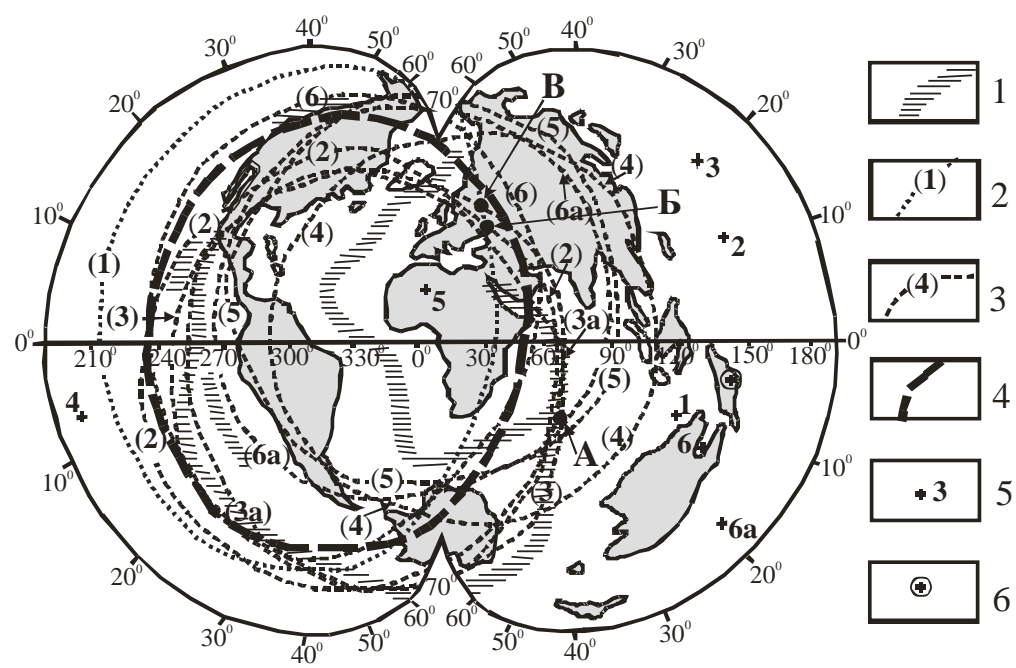

Рис. 2. Пространственное положение дофанерозойских палеомагнитных экваторов Земли [Оровецкий, Коболев, 2006]:

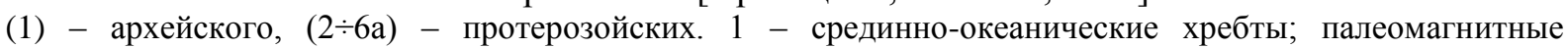
экваторы: 2 - планетарные; 3 - осредненные; палеомагнитные полюса: 4 - планетарные; 5 - осредненные. Буквенная индексация точек: А - тройная точка Родригес; Б - Полтавский рифтогенный узел (пересечение Восточно-Европейско-Мозамбикского с Сарматско-Туранским горячим поясом); В - Верхневолжский мантийный плюм (пересечение Восточно-Европейско-Мозамбикского с КаспийскоБалтийским горячим поясом).

Fig. 2. Prephanerozoic magnetic equators [Orovetsky, Kobolev, 2006]:

Equators: Archean - (1); Proterozoic - (2),-6a; 1 - midocean ridges; paleomagnetic equators: 2 - planetary; 3 - averaged; points: A - Rodriges triple junction (the Indian Ocean); $B$ - the Poltava riftogen junctio (intersection of the East-European-Mozambican and Sarmatian-Turanian hot belts); $C$ - The upper Volga mantle plume (the center of old the East European platform). 

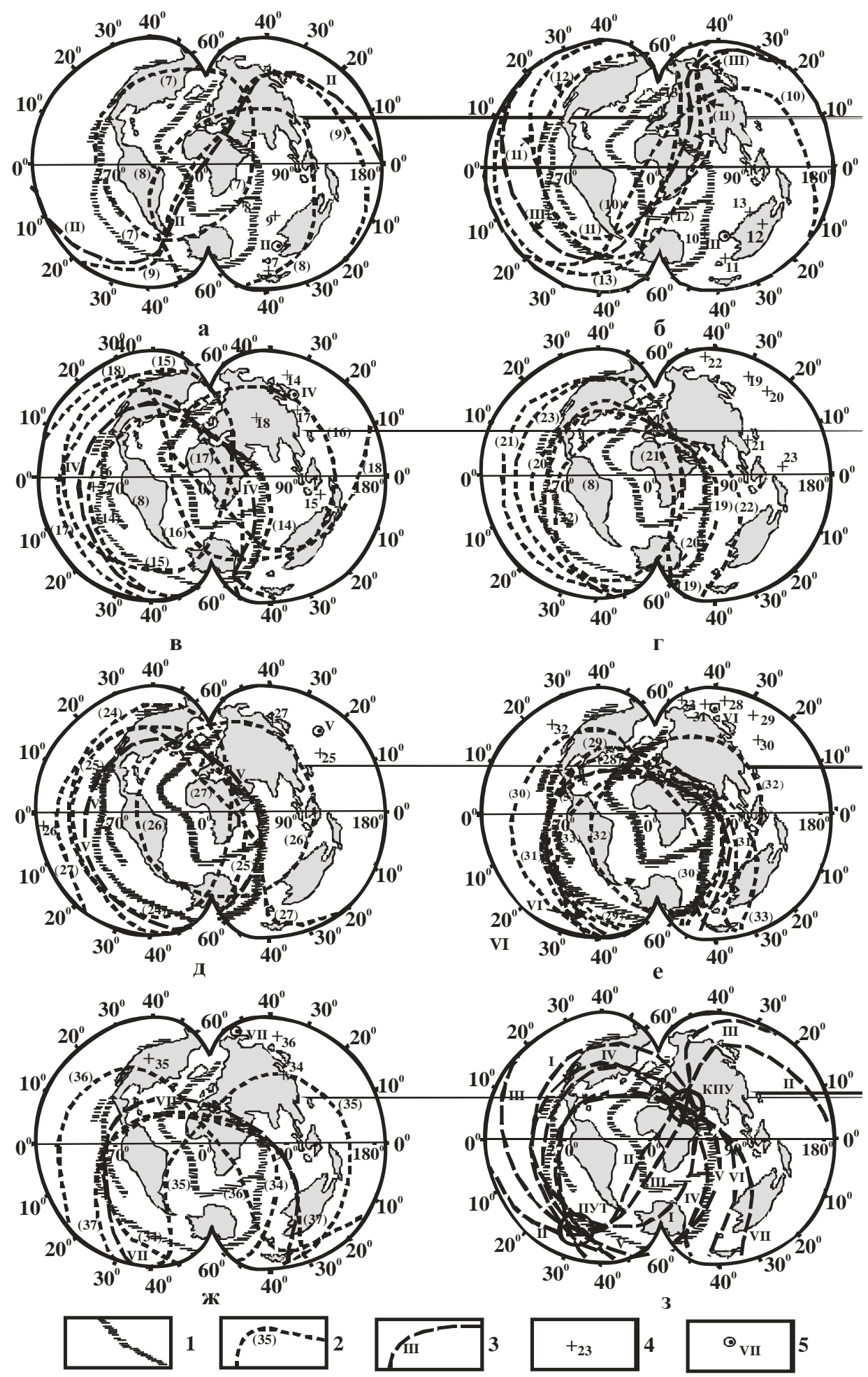

Рис. 3. Пространственное положение палеозойских палеомагнитных экваторов Земли [Оровецкий, Коболев, 2006]:

а - кембрийских; б - ордовикских; в - силурийских; г, д - девонских; е - карбоновых; ж - пермских; 3 - осредненных домезозойских. 1 - срединно-океанические хребты; палеомагнитные экваторы: 2 - планетарные; 3 - осредненные; палеомагнитные полюса: 4 - осредненные; 5 - планетарные.

Fig. 3. Paleozoic magnetic equators (after Orovetsky, Kobolev, 2006). Equators:

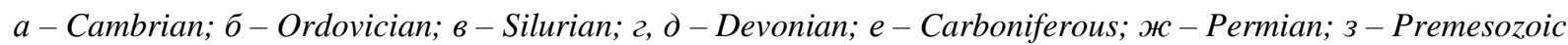
average; 1 -midocean ridges; palaeomagnetic equators: 2 - planetary; 3 -average; palaeomagnetic poles: 4 - averaged; 5 - planetary. 

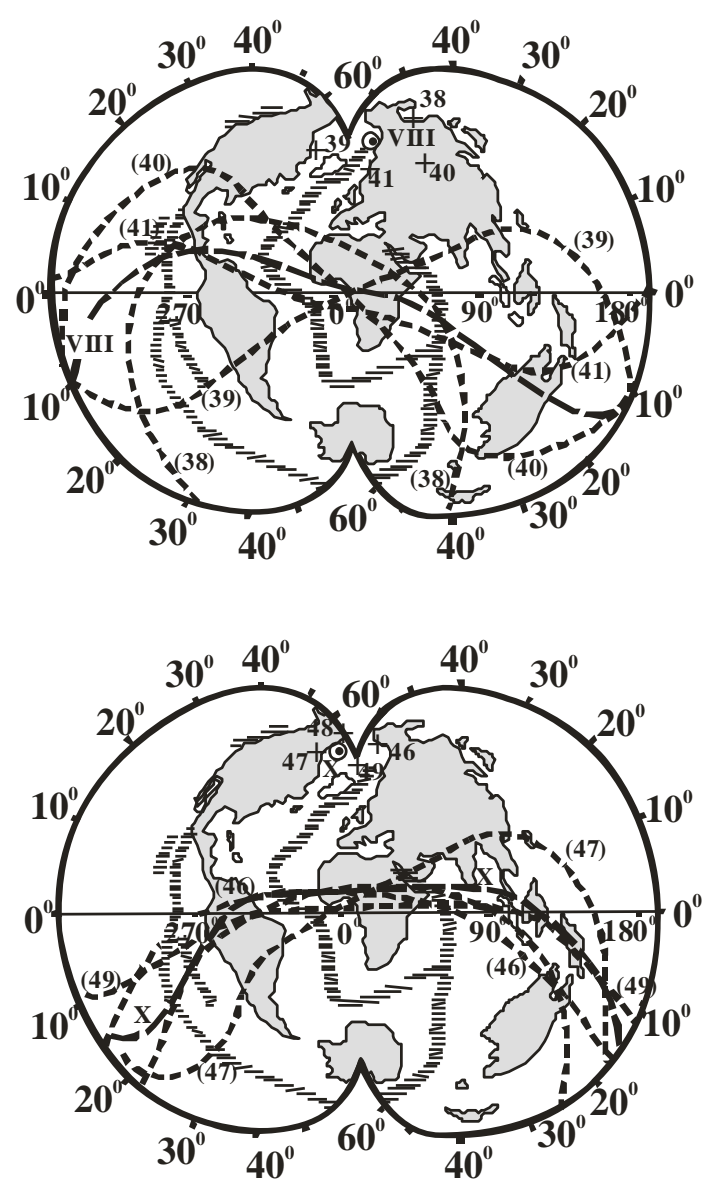

Это означает, что указанные архитектонические структуры с их ротационным рифтингом, воздыманием и глубинным магматизмом являются интегральными геотектоническими сооружениями. По сути, они представляют собой древние (в основном протерозойские), ротационного происхождения геотектонические образования, постепенно сложившиеся в результате интенсивного и перманентного магматизма по тектонически ослабленным приэкваториальным зонам Земли. В качестве примера, приведем возраст срединно-океанического хребта Карлсберг (Индийский океан) по его взаимоотношению с глубинным правосторонним сдвигом Оуэн. Будучи определенным как вендский, этот сдвиг смещает рифтовую долину хребта Карлсберг на расстояние около 300 км. Тем самым его срединно-океаническая структура автоматически становится еще более древним - довендским тектоническим сооружением [Коболев, Оровецкий, 2006]. Однако это отнюдь не исключает более раннего рифтогенеза, который может быть зашифрован в архейских разрезах и по которым сейчас отсутствует достаточная палеомагнитная информация. Неоднократное наложение более молодого тектономагматизма привело к угнетению, редукции или полному исчезновению предыдущих признаков георифтогеналей, кроме их генеральных направлений. Отсюда возникло широко распростра-

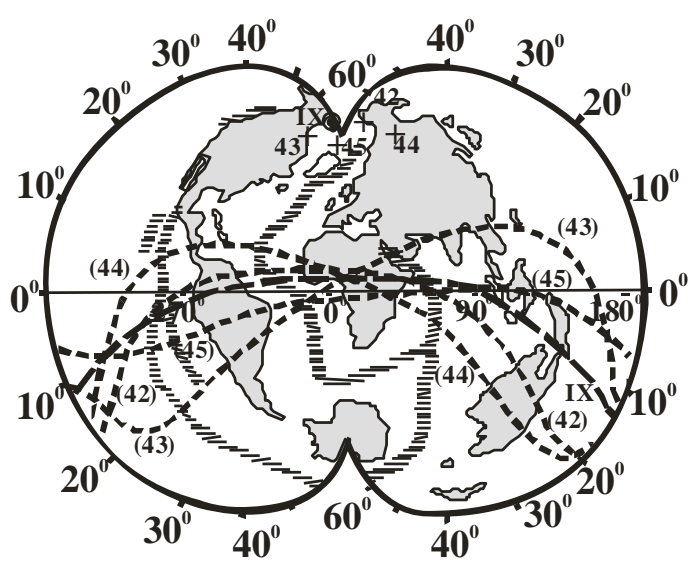

Рис. 4. Пространственное положение мезозойских палеомагнитных экваторов Земли в триасе (a), юре (б) и мелу (в) [Оровецкий, Коболев, 2006]. Условные обозначения на рис. 3

Fig. 4. Mesozoic magnetic equators in Triassic (a), Jurassic (б) and Cretaceous (в) [Orovetsky, Kobolev, 2003]. The notation are in Fig.3

ненное мнение об относительной молодости срединно-океанических хребтов. Однако в этих случаях речь должна идти не о времени заложения указанных архитектонических структур с их рифтогенами, а о событиях последней тектономагматической активизации указанных глобальных структур раздвига.

Линейные поднятия срединно-океанических хребтов динамически связываются с выгибанием и рифтингом земной коры за счет подвода сверхкрупных объемов глубинного вещества мантийных магматогенов. Такое сосредоточенное и перманентное перераспределение жидкофазного мантийного материала должно непременно сопровождаться в гравитационном поле Земли билатеральной компенсационной просадкой перекрывающих твердофазных толщ территорий, прилегающих к срединно-океаническим хребтам. Этими территориями представляются соседствующие с хребтами талассократоны - крупные участки ложа океанов, обнаруживающие общую тенденцию к погружению. Их вещество, достигая своей подошвой глубинных высокотемпературных сфер Земли, претерпевает соответствующую фазовую трансформацию и продолжает участие в ротационном, экваториально направленном цикле.

Поскольку к срединно-океаническому хребту перемещаются сверхзначительные по величине массы, компенсирующими и такими же по объему 
должны стать отрицательные морфоструктуры океанов, заложение которых адекватно времени образования срединно-океанических хребтов. Просадка их периферии (судя по глубине сейсмофокальных зон Заварицкого-Беньофа и наличию в них щелочных разновидностей базитов и гипербазитов) глубинная и связана, по-видимому, с низами мантии.

Обращает на себя внимание, приводимая на всех мелкомасштабных геотектонических картах не прямолинейная, а серпообразная форма разделительной “водораздельной” морфокинематической границы в Тихом океане с обращением вогнутой стороны на запад, что обычно свидетельствует о наклонном, в ту же сторону, залегании поверхности раздела. Конфигурация границы напоминает оползневой цирк и, тем самым, позволяет предположить, что ЗападноТихоокеанская депрессия образовалась при западном гравитационном сползании масс океанической коры с формированием во фронтальной своей части сейсмофокальной, наклоненной под Азиатский континент, зоны Заварицкого-Беньофа. Не последнюю роль в этом западном перемещении, по-видимому, играла инерционность минеральных масс при восточном вращении Земли. Поверхностью сползания могла служить кровля воздымающихся высокоразогретых нижнемантийных образований, ротационно и перманентно перемещающихся к срединно-океаническому хребту, как это показано исследованиями ГСЗ для Атлантического океана [Павленкова, 2004]. Такое погружение привело к формированию переходных зон Тихоокеанского типа, где глубинный магматизм представлен не толеитами - ультраметагенными производными океанической мантии, а выдавленными расплавами (инжекторный магматизм) щелочных ультрабазитов ее недеплетированной части, слагающих также основания краевых морей и пяти гигантских морфоструктур центрального типа, расположенных непосредственно вдоль восточной маргинальной части Азиатского континента [Романовский, 1999].

Указанные морфоструктуры (рис. 5), достигающие размеров в диаметре порядка 1,5-2,0 тыс. км, наследуют простиранию здесь протерозойского палеомагнитного экватора (4) (см. рис. 2). Они контролируются на поверхности ультраметагенными S-гранитоидами - продуктом четырехкратной, между 200 и 70 млн лет [Романовский, 1999] температурной мезо-кайнозойской переработки континентальной коры, что может восприниматься как верхний рубеж термодинамической активизации. Насыщенность гранитоидов базитами, гипербазитами и их щелочными разновидностями однозначно свидетельствует о наличии на глубине температурно активизированной мантии.

Гигантские морфологические аномалии располагаются между Индонезией и Чукоткой на протяжении свыше 10 тыс. км. Данные сейсмической томографии [Inoue et al., 1990] свидетельствуют, что под морфоструктурами находится трансмантийная низкоскоростная (с отклонением относительно принятой референц-модели от - 0,3 до $-0,5$ км/с) аномалия.

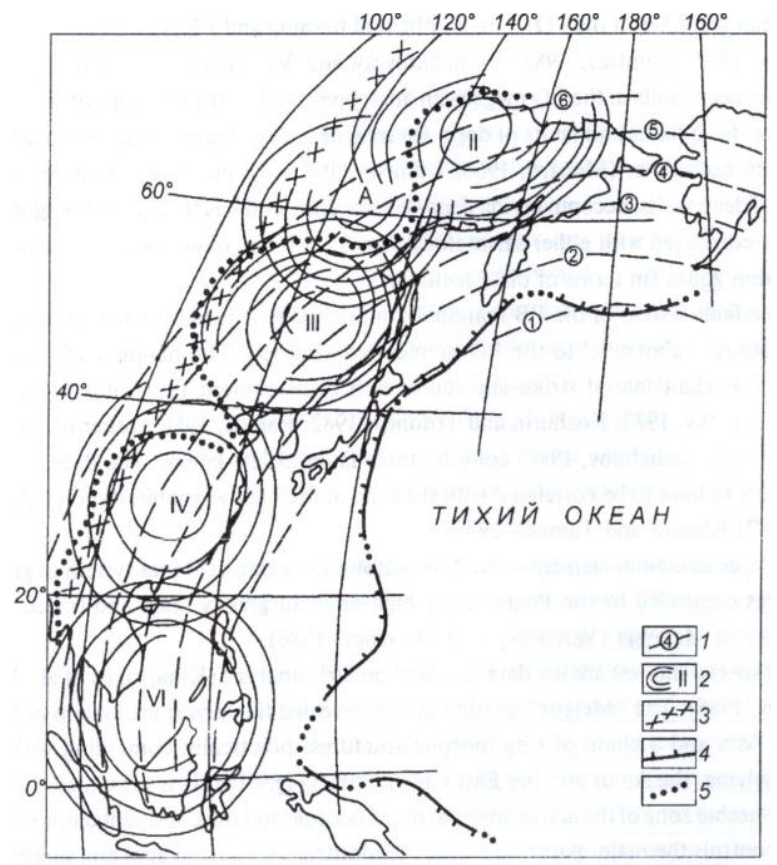

Рис. 5. Мегаморфоструктуры центрального типа Востока Азии (по [Романовский, 1999], упрощено):

1 - Циркумтихоокеанская система глубинных разломов, 2 - мегаморфоструктуры (по мере возрастания римской оцифровки соответственно): Яно-Колымская, Алданская, Амурская, ВосточноКитайская, Малайзийская; 3 - тектоническая зона Вебирс (Верхояно); 4 - глубоководные желоба; 5 - границы Тихоокеанского пояса

Fig. 5. Megamorphostructures of a central type, Eastern Asia (after Romanovsky, 1978, simplified):

1 - the Sircumpacific system of deep faults; 2 - megamorphostructures (as Arabicc numerals grow - Yuano-Kolyma, Aldan, Amur, East Chinese, Malaysian respectively); 3 - the Vebirs tectonic zone (Verkhoyano); 4 - deepwater trenches; 5 - the boundaries of the Pacific belt

В пределах глубин 80-150 км ее форма близка к линейной; по мере дальнейшего углубления, она сокращается в размерах, и на границе с внешним ядром Земли становится близкой к изометричной с центром под Восточно-Китайской морфоструктурой. Таким образом, можно с достаточной степенью уверенности говорить о принадлежности перечисленных морфоструктурных аномалий центрального типа к мультимагматогенам Восточноазийских суперплюмов. Формирование и 
последующая их эволюция сопровождаются интенсивной сейсмичностью, как это показано для известного Спитакского землетрясения на Малом Кавказе [Оровецкий, 1990; Orovetsky, 1999], а это, в свою очередь, указывает на продолжающееся их развитие.

По-видимому, близкая экстремальная сейсмотектоническая обстановка сложилась 26 декабря 2004 г. и 28 марта 2005 г. в современной экваториальной области Земли на юге Малазийского суперплюма в виде крупнейших землетрясений, происшедших в Индийском океане, неподалеку от о-ва Суматра. В пределах его кольцевой морфоструктуры плотность теплового потока находится преимущественно между 100 и $200 \mathrm{мBT} / \mathrm{M}^{2}$, в то время как за его пределами - в пределах 25-50 мВт/м² [Туезов, 1988]. Можно было предположить, что эти сейсмические события связаны с очередной глубинной магматической подпиткой указанного плюма и производной компенсационной просадкой его периферии, установленной, в частности, в Малаккском проливе, где она сопровождалась разломообразованием [Оровецкий, Коболев, 2006]. Впоследствии указанное предположение было подтверждено результатами сейсмотомографических исследований [Старостенко и др., 2005]. На глубинах 570-700 км под морфоструктурой Малазийского суперплюма, обнаружена низкоскоростная $(-0,25$ км/с относительно принятой референц-модели) аномалия, зафиксированная шестью широтными сейсмотомографическими пересечениями верхней мантии. Эта аномалия зафиксирована между $0^{0}-5^{0}$ с.ш. и $95^{\circ}-103^{\circ}$ в.д., и только на сечении $5^{0}$ с.ш. мещается, несколько расширяясь к востоку, где попадает непосредственно под центральную часть Малазийского плюма (рис. 6). Таким образом, низкоскоростная аномалия находится непосредственно под очагами указанных землетрясений, имеющих координаты: 26 декабря 2004 г. $-3^{\circ}$ с.ш. и $96^{\circ}$ в.д. и 28 марта 2005 г. $-2^{\circ}$ с.ш. и $97^{\circ}$ в.д. [Старостенко и др., 2005]. Эти землетрясения, повидимому, можно расценивать в качестве тектонического отклика на пространственное перемещение вещества в указанной аномалии, которая отождествляется нами с крупным, мощностью свыше 100 км магматогеном, активизированным в настоящее время.

Следует отметить, что, наряду с аномалией высокого теплового потока [Туезов, 1988] и непосредственно локальной низкоскоростной аномалией в ее низах [Старостенко и др., 2005], гравитационная аномалия интенсивностью до 30 мГал, локальный свод до 7 м по поверхности геоида и центриклинально напряженная область в основании литосферы образуют единую сложную вертикальную термодинамическую систему (рис. 7).

Активизация Малазийского суперплюма, начавшись еще, по-видимому, в протерозое по палеомагнитному экватору (4), (см. рис. 2, 5), функционирует на его приэкваториальном участке и по сегодняшний день.

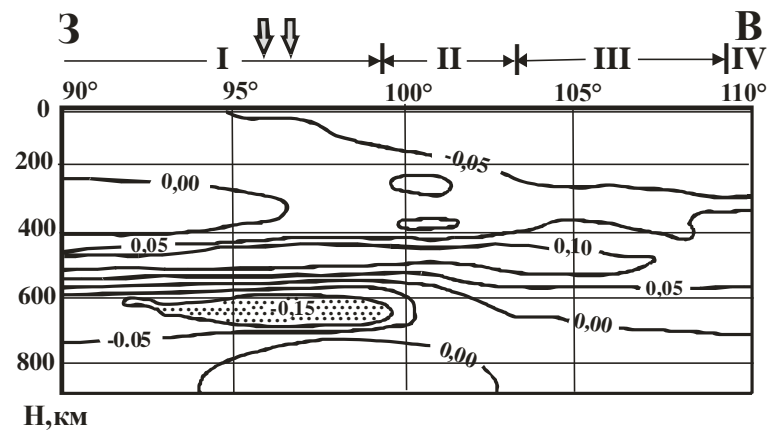

Рис. 6. Схема глубинного строения югозападного сектора Малазийского суперплюма вдоль экватора (по [Старостенко и др., 2005]): Изолинии - скоростные невязки (км/с) относительно принятой референц-модели. Крап глубинный магматоген. Римские цифры: I-IVсоответственно - Индийский океан, о. Суматра, пролив Каримата, о-в Калимантан. Стрелки проекции очагов землетрясений на современный экватор

Fig. 6. Scheme of the deep structure of the southwestern sector of the Malaysian superplume along the equator (according to [Starostenko et al., 2005]):

Isolines - high-speed discrepancies $(\mathrm{km} / \mathrm{s})$ relative to the adopted reference model. Crap is a deep magmatogen. Roman numerals: I-IV - respectively Indian Ocean, o. Sumatra, Karimata Strait, Kalimantan Island. Arrows - projections of earthquake foci on the modern equator

Указанное ставит под сомнение существование в этом регионе субдукции Австрало-Индийской плиты в северо-восточном направлении, как это предлагается, например, в работе [Puspito et al., 1993]. Эту сейсмогенетичесую границу между Индийской и Тихоокеанской плитами можно, вероятно, соотносить с пограничной областью между соответствующими планетезималями. Обращаясь к ретроспективе, отметим, что в этом же районе в 1883 г. произошло известнейшее и столь же разрушительное извержение вулкана Кракатау с выбросом пирокластики объемом свыше 18 куб. км и высотой волны цунами до 20 м [Советский..., 1990]. Следует также обратить внимание, что глубинный очаг упомянутого вулкана расположен непосредственно на приэкваториальном участке палеомагнитного экватора (4), в Зондском проливе, между островами Суматра и Ява (см. рис. 2).

Корреляция геоструктур главных поверхностей Земли - геоида, раздела М и субъядра - на сейсмотомографической модели в постановке задачи миграции литосферных плит под воздей- 
ствием конвекционного механизма, априори подразумевала, что передвижение последних, особенно усугубленное их вращением, полностью исключает согласованность общих тектонических планов на указанных уровнях из-за расположения между ними верхней астеносферы - области перемещения этих плит.

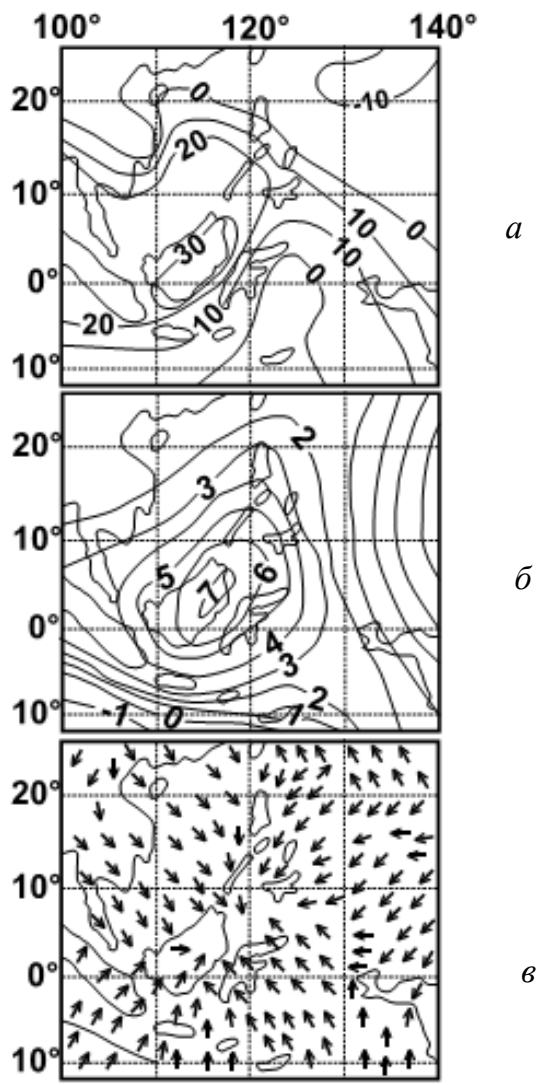

Рис. 7. Вертикальная термодинамическая система в основании Малайзийского суперплюма [Романовский, 1999]: $a$ - аномалия силы тяжести в редукции свободного воздуха мГал; б - аномальный свод по поверхности геоида, м; в - центриклинально напряженная область в основании литосферы

Fig. 7. The vertical thermodynamic system at the base of the Malaysian superplume (according to [Romanovsky, 1999]):

$a$ - gravity anomaly in the reduction of free air, $m G a l ; b$ - anomalous arch along the geoid surface, $m ; c$ - the centriclinal stress at the base of the lithosphere

Однако, вопреки предположениям, результаты соответствующего анализа такую связь показали: она доказана в виде общих СЗ-ЮВ структурных направлений на разделе М и поверхности субядра [Оровецкий, Коболев, 2006]. Это однозначно указывает на отсутствие миграции литосферных плит. Взамен, под действием исключительно ро- тационных напряжений, латерально и в разных направлениях перемещается по жидкофазному разделу кровли субъядра вся оболочка Земли в целом. При этом, нужно обязательно подчеркнуть, что относительное расположение на ее поверхности (геоиде) всех более ранних, геоисторически сложившихся глобальных геотектонических структур, остается неизменным. Таким образом, результаты наших исследований указывают на отсутствие каких-либо относительных латеральных перемещений планетарных морфоструктур, начиная с докембрия и заканчивая поздним палеозоем.

Георифтогенали срединно-океанических хребтов продолжают себя в континентальных своих аналогах, совпадающих с ними не только по палеомагнитному, но и по геологическому возрасту. Это наводит на мысль о возможной протерозойской рифтогенной делимости тектоносферы, общей как для континентальной, так и океанической земной коры, что сближает их по времени образования. К такому же заключению приводит наличие общих для них глобальных изотопно-геохимических аномалий "Dupal" со временем образования более 3 млрд. лет [Hart, 1984]. Поэтому представляется, что пересечение древними палеомагнитными экваторами современных границ между континентами и океанами, a, также принимая во внимание такой же древний 3-1,5 млрд лет - возраст верхней мантии океанов [Трухалев и др., 1993], можно допустить еще более раннее, догеологическое, существование этих разделов, что полностью отвечает современной аккреционной теории происхождения Земли.

Развивая это положение, следует в первую очередь обратить внимание на различные содержания “некогерентных" $\mathrm{Na}, \mathrm{Rb}, \mathrm{Cs}, \mathrm{Sr}, \mathrm{Ba}$ и радиоактивных (K, U, Th) элементов в континентальной и океанической корах. Если континентальная кора характеризуется чрезвычайно высокой степенью обогащения указанными легкоплавкими ингредиентами и такой же теплогенерацией, то для океанической - наоборот, типичным является присутствие "когерентных" (Ti, Zr, $\mathrm{Nb}, \mathrm{Ta}, \mathrm{V}, \mathrm{Cr}, \mathrm{Ni}$ ) элементов, не играющих роль теплогенераторов. В этом же ряду стоит и плотность теплового потока. Усредненная его величина по крупным площадям составляет для континентов и океанов соответственно 60 и $90 \mathrm{мBт} / \mathrm{M}^{2}$. Таким образом, мантия океанов, несмотря на чрезвычайную бедность теплогенерирующими элементами, оказалась в 1,5 раза более прогретой, нежели континентальная. В этом случае, по-видимому, не обошлось без разной, большей для океанической коры, теплопроводности пород, что возвращает нас к исходному тезису о гетерогенной аккреционной модели Земли с еe различным вещественным планетезимальным составом.

Согласно расчетам В. А. Магницкого [2006], температура мантии Земли близка к солидусной. 
Это обеспечивается, по нашему мнению, кондуктивным ее прогревом из-за частой ротационной рифтогенной делимости (см. рис. 2-4). В физическом смысле солидусная температура означает селективное плавление изначального мантийного вещества с последующей сепарацией легкоплавких ингредиентов от тугоплавкой матрицы. Достаточность их содержания приводит к формированию мощной континентальной коры, а недостаток знаменуется образованием фракционатов океанической коры - гранитоидов преимущественно гранофирового состава, которые принимаются отдельными исследователями [Белоусов, 1989; Павленкова, 2004 и др.] за реликты примитивной континентальной земной коры. Такой механизм снова-таки приводит нас к исходному тезису о разном вещественном составе аккреционного вещества Земли.

Вместе с миграцией виртуальных палеомагнитных полюсов меняют свое пространственное положение и соответствующие им виртуальные палеомагнитные экваторы. Спонтанность возникновения возбуждающей гравитационной неоднородности - основной причины их перемещения подразумевает пересечение палеомагнитных экваторов и предопределенных ими глубинных рифтогенных структур: на севере Аравийского моря, в тройной точке хр. Родригес (центральная часть Индийского океана) и др.

Однако наиболее масштабными являются пересечения усредненных палеомагнитных экваторов, выделенных нами графически в виде двух крупных палеоэкваториальных узлов (см. рис. 3, $u$ ). Красноморский палеоэкваториальный узел (КПУ) располагается на Нубийско-Аравийском своде Африканского континента. Сейсмотомографическими исследованиями последних лет под ним выявлен мантийный плюм с глубиной заложения 2900 км [Dapeng, 2001], что соответствует кровле слоя Е. Такая глубинная тектоническая ситуация объясняет происхождение НубийскоАравийского свода с его тройным рифтогенным сочленением Афар. Палеоэкваториальный узел Туамоту (ПУТ) располагается антиподально предыдущему на земной коре океанического типа, в юго-восточной части Тихого океана (см. рис. 3) и контролирует изотопную аномалию "Sopita". Эта аномалия входит в состав древней (свыше 3 млрд. лет) изотопной аномалии “Dupal”, что, по-видимому, делает архейским и генетически связанный с ПУТ Красноморский палеоэкваториальный узел. Под аномалией "Sopita", как и в случае с КПУ, сейсмической томографией обнаружена трансмантийная низкоскоростная аномалия, отождествляемая с поднимающимся из субъядра суперплюмом [Inoue, 1990; Maryama, 1994]. Таким образом, палеоэкваториальные узлы - продукт наших теоретических построений - нашли свое экспериментальное сейсмотомографическое воплощение в виде двух сверхглубинных магма- тически проницаемых областей. По всей видимости, такая корреляция не может носить случайный характер и быть обычным совпадением фактов.

К одной из аналогичных, но палеозойской, мультиинтрузий относится Центральноазийский суперплюм (рис. 8). Идентифицирован он по трансверсальной неоднородности, выявленной методом сейсмической томографии [Бугаевский, 1978]. Глубина заложения суперплюма соответствует поверхности субъядра Земли, где на границе с подошвой мантии зафиксирован ее разрыв $\left(\mathrm{Vp}_{\mathrm{H}} \geq 0\right)$. Площадь суперплюма на дневной поверхности - около 6 млн. кв. км. Через всю мантию Центральноазийский суперплюм, как и Восточноазийские, прослеживается в виде вертикальной низкоскоростной сложного строения зоны, которая на поверхности венчается Байкальским мегасводом, одноименным рифтогеном и полифазным (рекуррентным) кембрий-четвертичным магматизмом.

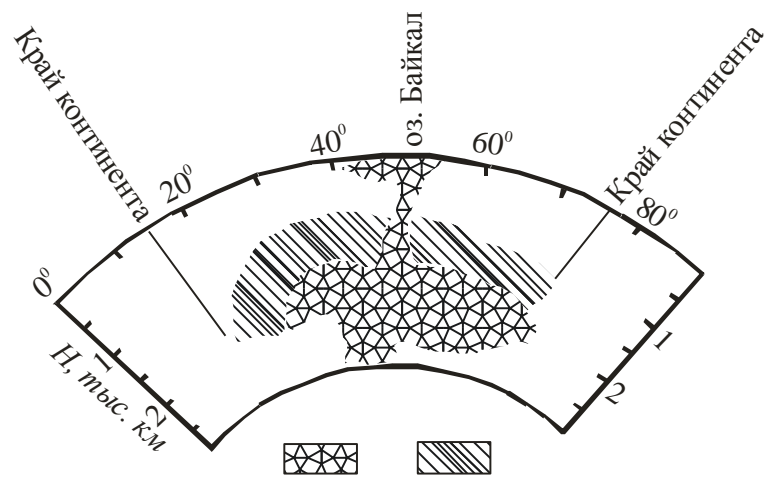

Рис. 8. Схема глубинного строения Центральноазийского суперплюма [Бугаевский, 1978]

Сейсмологические аномалии: 1 - высокоскоростная; 2 - низкоскоростная; 3 - разрыв сейсмологической границы между жидким внешним ядром и перекрывающей мантией.

Fig. 8. Sketch map of the Central Asian super plume [Bugaevsky, 1978].

Seismological anomalies: 1 - high velocity; 2 - low velocity; 3 - break in seismological boundary between the outer liquid subcore and overlain mantle.

В тектоническом отношении Центральноазийский суперплюм наследует локальному участку крупной, длиной до 6000 км, Карачи-Верхоянской сейсмотектонической зоны, предопределенной кембрийским палеомагнитным экватором (7), (см. рис. 3). Она на крайнем юго-западе, от г. Карачи следует вдоль р. Инд и, повторяя тектоническую границу между Афганской и Индийской глыбами, продлевается далее на северо-восток через рифтоген оз. Байкал до самого Верхоянья. В этой же сейсмотектонической зоне раннекай- 
нозойский, возможно рекуррентный и такой же плюмовый магматизм зафиксирован под $\mathrm{Ce}$ верным Тянь-Шанем. Думается, что аналогичные мультимагматогены мантийных плюмов слагают генетические основания, расположенных в этом регионе, наибольших на Земле, морфокинематических аномалий Гималаев и Тибета [Оровецкий, Коболев, 2006].

Еще одним из показательных примеров такого рода служит Верхневолжский суперплюм [Оровецкий, 1990; Orovetsky, 1999]. Он зародился в центре будущей Восточно-Европейской платформы в виде одного из локальных гранит-зеленокаменных мультимагматогенов трансконтинентального Восточно-Европейско - Мозамбикского горячего пояса, предопределенного архейским палеомагнитным экватором (1), (см. рис. 2). Уже в раннем протерозое Верхневолжский мантийный плюм, принявший размеры суперплюма, становится тектоническим центром, от которого радиально расходятся структуры протоплатформ и рифтинг-протогеосинклиналей - реликтов древней архейской коры, “взломанной” при сводообразовании. На рубеже раннего и позднего протерозоя завершилась кратонизация ВосточноЕвропейской платформы, связанная, по-видимому, с достижением Верхневолжским суперплюмом своих наибольших размеров. Следующий еe деструктивный этап венчается рифейской активизацией того же Верхневолжского суперплюма. Эта активизация привела к очередному, но меньшему по масштабам, сводообразованию с формированием в центре свода тройного торцового сочленения Волыно-Оршанского, Пачелмского и Среднерусского авлакогенов и образованию по его периферии одновозрастных анортозит-рапакивигранитных мультимагматогенов [Оровецкий, 1990; Orovetsky, 1999]. Динамика последующих активизаций Верхневолжского мантийного суперплюма (генетического основания Восточно-Европейской платформы) зашифрована в ритмичности трансгрессивного цикла на ее территории в фанерозое [Белоусов, 1989]. Таким образом, нельзя исключить присутствие в качестве генетического основания древней Восточно-Европейской платформы Верхневолжского суперплюма, который проявлял себя в виде соответствующих тектоно-магматических активизаций в одном и том же месте с архея по квартер. В связи с тем, что на территории всех древних платформ Земли установлен еще Н. С. Шатским плитный авлакогенный этап их развития, думается, не будет слишком радикальным предположение о таком же плюм-тектоническом механизме образовании последних.

Рассматриваемая проблема горячих поясов Земли в виде ротационно-магматогенного механизма рифтообразования представляет особенный интерес для решения общих вопросов геотектоники такого крупного и геологически закрытого региона, каким является древний материк Антарктида. Главные особенности его строения скрыты от наблюдения ледяным покровом. Потому получение новых независимых данных и корреляция их с результатами предыдущих исследований, приобретенных в основном на континентальной окраине, представляется существенным подспорьем в познании этого, во многом еще загадочного континента. Сказанное относится преимущественно к его рифтогенной природе. В связи с этим, известный исследователь Антарктики Г. Э. Грикуров пишет: “Накопившийся материал, в первую очередь геолого-геохронологические данные, позволяет аргументировано проследить признаки рифтогенных процессов в глубь геологической истории”. И далее: “Практически с момента заложения антарктической континентальной коры прослеживается тенденция к ее деструкции, что выражается в развитии рифтоподобных и рифтовых зон на всех этапах тектонической эволюции" [Грикуров, 1989, с. 179]. Изотопные $\mathrm{U}-\mathrm{Pb}$ датировки наиболее древнего (рейнерского) антарктического изверженнометаморфического комплекса лишь в одном случае показали по эндербитам возраст 3,2 млрд. лет (архей), тогда как в остальных их разброс составил от 2,4 до 0,46 млрд лет [Хаин, Божко, 1988], что соответствует протерозою и раннему фанерозою. Согласно нашим данным (рис. 9), один архейский (1), шесть протерозойских (2), (3), (3a), (4), (6), (6а) и одиннадцать палеозойских (7), (12), (13), (15), (16), (20), (21), (24), (25), (26), (27) (см. рис. 2-4) палеомагнитных экваторов пересекают по разным направлениям материк Антарктиды.

Такое массовое и пространственно сосредоточенное, 18-разовое пересечение рифтообразующими палеомагнитными экваторами континентальной коры древней аккреционной глыбы Земли в период с архея по средний палеозой не могло не привести к формированию в месте их проявления обширнейшей по своим масштабам планетарной области растяжения. В отличие от Г. Э. Грикурова, который связывает это растяжение с проблематичным “неравномерно-прогрессирующим расширением Земли” [Грикуров, 1989], мы приходим к выводу, что общее рифтогенное состояние земной коры обязано здесь конкретному явлению ротационного рифтинга. Многократно повторяющееся, кратное ротационному, растяжение привело к подъему из субъядерной области Земли цокольного суперплюма, как это показано в случае с древней Восточно-Европейской платформой. Его внедрение ознаменовалось подъемом территории и образованием, вследствие этого, на месте изначальной планетезимальной глыбы Земли, материка Антарктида. Наличие в ее недрах древнего мультимагматогена косвенно отображено данными формационного анализа. По его результатам, в стратиграфическом разрезе древней 
Антарктической платформы с венда по квартер периодически отмечаются перерывы в осадконакоплении, а в промежутках - распространение маломощных формаций, но континентального типа [Хаин, 1979], что знаменует высокое стояние рельефа в этот отрезок геологического времени.

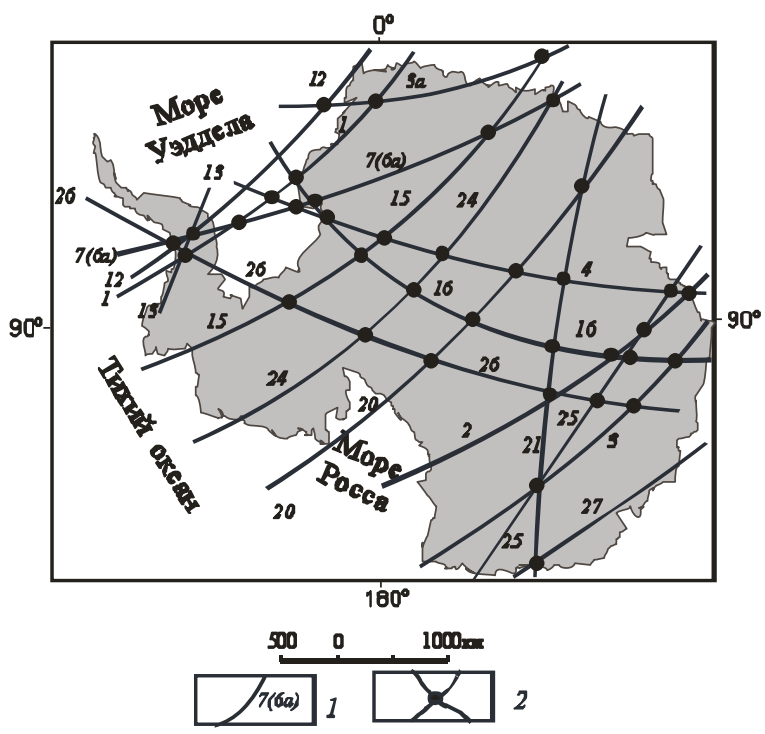

Рис. 9. Схема расположения рифтогенных узлов в Антарктиде

[Оровецкий, Коболев, 2006]:

1 - палеомагнитные экваторы; возраст палеомагнитных экваторов: (1) - архей; (2-6а) - протерозой; (7) - кембрий; (12) и (13) - ордовик; (16) силур; (21-26) - девон; в скобках - рекуррентность рифтогенеза; 2 - рифтогенные узлы

\section{Fig. 9. Palaeomagnetic equators in Antarctica} [Orovetsky, Kobolev, 2006]:

1 - paleomagnetic equators and their age: (1) Archean; (2-6a) - Proterozoic; (7) - Cambrian; (12) u (13) - Ordovician; (16) - Silurian; (21-26) Devonian; in brackets - their recurrent superposition); 2 - riftogenic junction

Внедрение суперплюма осуществлялось главным образом под восточную часть материка, что привело к горстовому в настоящее время ее строению. Одновременно происходило компенсационное погружение соседних регионов Западной Антарктиды и фундамента морей Росса и Уэделла. Граница этой компенсации проходит сейчас между Восточной и Западной Антарктикой в виде складчатой, длиной до 4 тыс. км, системы Трансантарктических гор и сопряженных с ними складчатых зон Земли Мэри Бэрд, гор Улсуэрт Уитмор, Пенсакола и др. [Коболев и др., 2010]. Время компенсационного погружения связывается Г.Э. Грикуровым с рубежом фанерозоя. Дальнейшая, мезо-кайнозойская история Антарктиды связывается нами с автономной эволюцией суперплюма, что вылилось в мощную, как и на древней
Восточно-Европейской платформе, завершающую плитную авлакогенную стадию развития ее древнего кратона.

O прекращении ротационного рифтообразования в Антарктиде, начиная с конца палеозоя, свидетельствует отсутствие на ее территории в это время палеомагнитных экваторов (см. рис. 2, 3, 9). Начиная с мезозоя, они покидают указанный материк и массово группируются в субширотном, близком к современному экватору, направлении (см. рис. 4).

\section{Заключение}

В итоге подчеркнем, что эмпирические данные показали: с ротационными рифтогенами связано большинство известных мантийных плюмов Земли. Ориентированные по радиусу Земли, они достигают поверхности жидкого субъядра, чем провоцируют глубинный плюмовый магматизм, как это показано, в частности, на экспериментальном материале Афарского, Туамоту, Центральноазийского и Восточноазийских суперплюмов. Поэтому представляется, что причина рифтообразования для всех случаев едина - подвод глубинного магматического материала. Однако воплощение этого процесса в верхней части оболочки Земли - строго индивидуализировано и напрямую зависит от того, с какой геологической средой этот процесс пересечется: континентальная или океаническая кора, более раннее тектоническое строение, предопределенное, в том числе, и ротационным режимом Земли, магматизм и другие не менее существенные факторы. В связи с этим, нужно отдать должное предвидению Е. Е. Милановского, который еще в 1976 г. писал: “формирование рифтовых поясов представляет глобальный процесс, захватывающий как океаны, так и континенты, но по-разному проявляющийся в пределах этих геоструктурных областей, и, очевидно, имеющий более глубинный механизм, чем те глубины, на которые распространяются в мантию различия между континентами и океанами" [Милановский, 1976, с.163]. На этом основании думается, что все попытки номенклатурной классификации рифтогенов путем присвоения им унитарных генетических черт не могут быть успешными. При детальном анализе упомянутые структуры растяжения могут оказаться эквивалентными более ранним тектоническим обстановкам, которые они деструктуризируют.

Предложенная система взглядов на структурную эволюцию Земли имеет в своей основе динамический ротационно-гравитационный механизм и сопровождающий его глубинный субъядерный магматизм. Латеральная миграция дневной поверхности происходит не по подошве литосферных плит, а на уровне основания твердой оболочки Земли, по жидкофазному, без пространственной дискретности, разделу кровли ее внешнего ядра. Указанный механизм привел к 
формированию на максимумах разновозрастных и разнонаправленных антиформ экваториальных вздутий планеты ротационных рифтогенов. Эти архиструктуры планетарного раздвига, образуя во времени сетку делимости тектоносферы, способствуют ее длительному кондуктивному прогреву поднимающимся перегретым субъядерным веществом. Тем самым создаются температурные условия для селективного плавления первичного, гетерогенного по составу, аккреционного субстрата. При этом образуются крупные области внутримантийных, инерционно реактивных сейсмических волноводов, в том числе и завершающая сепарация легкоплавких ингредиентов с выделением в случае их избытка мощной континентальной коры, а при недостатке - коры океанической. Не исключается такой же автометаморфический механизм образования дискретных областей верхней астеносферы совместно с полным спектром магматических расплавов.

Продвигаясь в том или ином направлении, мантийный субстрат может перемещать лежащие на нем отдельные блоки литосферы, разделенные глубинными разломами регматической сети на то или иное расстояние друг от друга. Возможен также их разворот в ходе течения этих потоков на различные углы и деформация. В качестве примера такого явления могут служить цепи островных дуг, палеодуг (зон скручивания коры) и островных архипелагов. В этом случае отпадает необходимость оперировать такими маловероятными с физической точки зрения понятиями как мантийные ячейки и мантийная тепловая конвекция и их производными атрибутами концепции плитовой тектоники - обдукционно-субдукционным механизмами [Филатьев, 2007].

Следует также отметить, что глубинные процессы, вызывающие глобальный рифтогенез, по всей видимости, были общими и имели место, начиная со времени образования жидкофазного внешнего ядра. Однако последующие тектонические преобразования в отдельных случаях разрушали древние рифты до степени полной современной неузнаваемости. И все-таки, даже оставшиеся их структуры, речь о которых шла выше, в настоящее время представляют существенный интерес для геотектонического анализа. Поэтому, будем считать, что исследования по проблеме находятся в самом начале пути. Представляется, что в дальнейшем необходимо всемерно развивать количественную и качественную стороны палеомагнитного опробования (в том числе и древнейших горных пород) и выявление на этой основе в первую очередь глубинной, ротационной по существу рифтогенной делимости Земли.

В зависимости от морфологической иерархии, глубинные магматогены, перемещаясь в виде мантийных диапиров или плюмов в верхнюю часть оболочки планеты, с одной стороны формируют над собой положительные знаковые формы рельефа, включая и древние платфор- менные области, а с другой - одинаковые с ними по общему объему компенсационные понижения вплоть до океанических депрессий.

В результате приходим к фундаментальному выводу: ротационно-гравитационный режим Земли, сопровождаемый во времени инициированным глубинным магматизмом, поддерживает ее сложную, неустойчивую механическую систему в состоянии перманентного структурообразования на уровне целостного, без пространственной дискретности, жидкого субъядра. С этих позиций производный ротационный рифтинг представляется основным объективно-случайным механизмом структурного преобразования тектоносферы Земли.

Что же касается тектоники литосферных плит, то выше была показана несостоятельность ее базисной динамической предпосылки - мантийной конвекции - из-за множественности (неустойчивости) результатов ее решения, что ставит, таким образом, указанную проблему в число неадекватных. И все же, несмотря на это, роль парадигмы тектоники литосферных плит представляется прогрессивной. Эта ее черта, прежде всего, состоит в наличии огромного массива по своей сути определяющих, ранее недоступных сведений о строении и составе преимущественно океанической тектоносферы. Однако критиковать упомянутую геотектоническую концепцию, не предлагая ничего взамен, было бы критиканством. Альтернативная система взглядов оптимально кратко изложена в предложенной статье. В основе гипотезы ГПЗ лежат эмпирические данные, а также разномасштабные, базисные для современной физики колебательные процессы, опирающиеся, в свою очередь, на всеобщий закон сохранения. По степени самодостаточности предлагаемая модель представляется в качестве недостающего звена между антиподальными сейчас геологическими мировоззрениями: фиксизма, чьи геоисторически сложившиеся научные каноны остались неприкосновенными, и мобилизма в новой его транскрипции.

\section{Список литературы}

Авсюк Ю. Н. Фактическое обоснование цикличности хода приливной эволюции системы Земля - Луна - Солнце / Ю. Н. Авсюк, И. И. Суворова // Материалы совещания “Фундаментальные проблемы геотектоники”. М. : ГЕОС, 2007. - С. 3-6.

Анфилогов В. Н. Мантийные плюмы: уровень генерации и механизм передачи энергии к поверхности Земли / В. Н. Анфилогов, Ю. В. Хачай // Фундаментальные проблемы геотектоники: матер. XL тектонического совещания, Т. I. - М. : ГЕОС, 2007. - С. 18-21.

Белевцев Р. Я. О термодинамической эволюции земной коры и тектонике плит / Р. Я. Белевцев, В. И. Блажко, С. И. Терещенко // Геофиз. журн. - 2016. - 38, № 6. - С. 118-136. 
Белоусов В. В. Основы геотектоники / В. В. Белоусов. - М. : Недра, 1989. - 382 с.

Бугаевский Г. Н. Сейсмические исследования неоднородности мантии Земли / Г. Н. Бугаевский. - К. : Наук. думка, 1978. - 184 с.

Виноградов Л. А., Кудрявцев В. Н. Ротационная горизонтальная составляющая изостазии. Апатиты: Препринт Геологического ин-та Кольского филиала АН СССР, 1987. - 48 с.

Гордиенко В. В. Процессы в тектоносфере Земли (адвекционно-полиморфная гипотеза) / В. В. Гордиенко. - Saarbrücken: LAP, 2012. - 256 c.

Гордиенко В. В. О гипотезе тектоники плит / В. В. Гордиенко // Геофиз. журн. - 2013. - 35, № 6. - C. 72-101.

Грачев А. Ф. Мантийные плюмы и проблемы геодинамики / А. Ф. Грачев // Физика Земли. 2000. - № 4. - С. 3-37.

Грикуров Г. Э. Континентальный рифтогенез в домезозойской эволюции земной коры Антарктиды / Г. Э. Грикуров // Тектонические процессы. - М. : Наука, 1989. - С. 172-183.

Добрецов Н. Л. Глубинная геодинамика / Н. Л. Добрецов, А. Г. Кирдяшкин, А. А. Кирдяшкин. Новосибирск : Изд-во СО РАН, 2001. - 409 с.

Добрецов Н. Л. Глобальная геодинамическая эволюция Земли и глобальные геодинамические модели / Н. Л. Добрецов // Геология и геофизика. - 2010. - Т. 51, № 6. - С. 761-784.

Коболев В. П. Горячие пояса Земли и Антарктанды (к проблеме происхождения) / В. П. Коболев, Ю. П. Оровецкий, Б. Я. Савенко, С. С. Чулков, П. А. Буртный, Е. Е. Карнаухова // Доп. НАН України. - 2010. - № 5. - С. 116-119.

Литасов К. Д. Состав и строение ядра Земли / К. Д. Литасов, А. Ф. Шацкий. - Новосибирск : Изд-во СО РАН, 2016. - 304 с.

Магницкий В. А. Внутреннее строение и физика Земли / В. А. Магницкий. - М. : Наука, 2006. $390 \mathrm{c}$.

Милановский Е. Е. Рифтовые зоны континентов / Е. Е. Милановский. - М. : Наука, 1976. - 279 с.

Михайлова Н. П. Палеомагнетизм анортозитов / Н. П. Михайлова, С. Н. Кравченко, А. М. Глевасская. - К. : Наук. думка, 1994. - 212c.

Оровецкий Ю. П. Мантийный диапиризм / Ю. П. Оровецкий. - К. : Наук. думка, 1990. $172 \mathrm{c}$.

Оровецкий Ю. П. Горячие пояса Земли / Ю. П. Оровецкий, В. П. Коболев. - К. : Наук. думка, 2006. - 312 с.

Оровецкий Ю. П. О рецензии Д. М. Печерского на книгу Ю. П. Оровецкого и В. П. Коболева "Горячие пояса Земли" / Ю. П. Оровецкий, В. П. Коболев // Геофиз. журн. - 2008. - 30, № 4. - C. 163-166.

Павленкова Н. И. Эмпирические основы ротационно-флюидной гипотезы глобального тектогенеза / Н. И. Павленкова // Геофиз. журн., 2004. - 26, № 6. - С. 41-60.
Печерский Д. М. Рецензия на книгу Ю.П. Оровецкого и В.П. Коболева "Горячие пояса Земли" / Д. М. Печерский // Геофиз. журн. 2008. - 30, № 4. - С. 160-162.

Романовский Н. П. Тихоокеанский сегмент Земли: глубинное строение, гранитоидные рудные системы / Н. П. Романовский. - Хабаровск : ДВО PAH, 1999. - $166 \mathrm{c}$.

Советский энциклопедический словарь. - М. : Советская энциклопедия, 1990. - 1632 с.

Старостенко В. И. Катастрофическое землетрясение 26 декабря 2004 г. у берегов Суматры: причины, последствия и уроки / В. И. Старостенко, В. С. Гейко, А. В. Кендзера, Т. А. Цветкова, И. В. Бугаенко, С. Т. Вербицкий // Геофиз. журн. - 2005. - 27, № 6. - С. 949-961.

Трубицын В. П. Тектоника плавающих континентов / В. П. Трубицын // Вест. РАН. - 2005. № 1. - С. 10-21.

Трубицын В. П. Реология мантии и тектоника океанических литосферных плит / В. П. Трубицын // Физика Земли. - 2012. - № 6. C. 3-22.

Трухалев А. И. Древние породы со СрединноАтлантического хребта / А. И. Трухалев, Ю. Е. Погребицкий, Б. В. Беляцкий // Отечественная геология. - 1993. - № 11. - С. 81-89.

Туезов И. К. Карта теплового потока Тихого океана и прилегающих континентов: (пояснительная записка) / И. К. Туезов. - Хабаровск : ДВО PAH, 1988. - 33 c.

Тяпкин К. Ф. Общность и отличие геологических разрезов тектоносферы Земли в пределах континентов и океанов / К. Ф. Тяпкин // Геология и полезные ископаемые мирового океана. 2012. - № 1(27). - С. 22-33.

Тяпкин К. Ф. Оценка новой ротационной гипотезы структурообразования в тектоносфере Земли с позиций диалектического материализма / К. Ф. Тяпкин // Науковий вісник НГУ. - 2013. № 1. - C. 11-24.

Тяпкин К. Ф. Новая ротационная гипотеза структурообразования и ее геолого-математическое обоснование / К. Ф. Тяпкин, М. М. Довбнич. Донецк : Ноулидж, 2009. - 342 с.

Филатьев В. П. Энергетика тектоники / В. П. Филатьев // Материалы совещания “Фундаментальные проблемы геотектоники”. - М. : ГЕОС, 2007. - С. 321-324.

Хазан Я. М. Тектоника плит: “за" и “за" / Я. М. Хазан // Геофиз. журн. - 2014. - 36, № 5. - C. 170-173.

Хаин В. Е., Божко Н. А. Историческая геотектоника. Докембрий / В. Е. Хаин, Н. А. Божко. М. : Недра, 1988. - 382 с.

Dapeng Zhao Seismic structure and origin of hotspots and mantle plumes. Earth and Planetary Letters, 2001, Vol. 192, p. 251-265.

Grasby S. E. Catastrophic dispersion of coal fly ash into oceans during the latest Permian extinction / S. E. Grasby, H. Sanei, B. Beauchamp // Nature Geoscience, 4, 2011, p. 104-107. 
Hart S. A large scale isotope anomaly in the Southern Hemisphere mantle. Nature, 1984, v. 309, № 5971, p. 753-757.

Inoue $\mathrm{H}$. Whole mantle $\mathrm{P}$-wave travel time tomography / H. Inoue, Y. Fuako, K. Tanabe et al. // Phys. Earth and Planet Iner.. - 1990. Vol. 59. - P. 294-328.

Larson R. L. Mantle plumes control magnetic reversal frequency / R. L. Larson, P. Olson // Earth and Plant. Sci. Lett. - 1991. - p. 437-447.

Lay T. The deep mantle thermo-chemical boundary: the putative mantle plume source / T. Lay // Geol. Soc. Amer. Spec. Paper 388. - 2005. - P. 193-205.

Maryama S. Plum tectonic / S. Maryama // J. Geol. Soc. Japan. - 1994. - Vol. 100, No. 1. - P. 24-49.

Orovetsky Yu. P. Mantle plumes. - Oxford \& IBH Publishing CO. PVT. LTD, New Delhi-Calcutta, 1999. -245 p.

Pavlenkova N. I. The Earth's degassing, rotation and expansion as sources of global tectonics / N. I. Pavlenkova // New Concepts in Global Tectonics Newsletter, 2012. no. 63, p. 31-53.

Pavlenkova N. I., Pavlenkova G. A. The upper mantle structure of the Northern Eurasia from the seismic profiling with nuclear explosions / N. I. Pavlenkova, G. A. Pavlenkova // New Concepts in Global Tectonics Journal. - 2017. - Vol. 5, No. 1, P. 6-26.

Puspito N. T. Three-dimensional P-wave velocity structure beneath the Indonesian region / N. T. Puspito, Y. Yamanaka, T. Miyatake // Tectonophysics. - 1993. - Vol. 220. - P. 175-192.

Shen Shu-zhong. Calibrating the End-Permian Mass Extinction / Shen Shu-zhong, Crowley James L., Wang Yue, Bowring Samuel A., Erwin Douglas H., Sadler Peter M., Cao Chang-qun, Rothman Daniel H., Henderson Charles M., Ramezani Jahandar, Zhang Hua, Shen Yanan, Wang Xiangdong, Wang Wei, Mu Lin, Li, Wen-zhong, Tang Yue-gang, Liu Xiao-lei, Liu Lu-jun, Zeng Yong, Jiang Yao-fa, Jin Yu-gan. // Science. - 2011. Vol. 334, no. 6061. - P. 1367-1372.

Storetvedt K. M. When global tectonics became a 'pathological science' / K. M. Storetvedt // New Concepts in Global Tectonics Journal. - 2014. Vol. 2. - P. 106-121.

Storetvedt K. M. Geoscientific urban legends / K. M. Storetvedt // New Concepts in Global Tectonics Journal, 2015. - Vol. 3. - No. 4. - P. 516-528.

\section{В. КОБОЛСВ}

Інститут геофізики ім. С. І. Субботіна НАН України, пр. Палладіна, 32, Київ, Україна, 79060, тел. +38(044)4242152, эл. почта kobol@igph.kiev.ua

\section{ЗЕМЛЯ: ВІРТУАЛЬНІСТЬ ТЕКТОНІКИ ПЛИТ, КОНФОРМНІСТЬ ФІКСИЗМУ ТА МОБІЛІЗМУ}

Мета. Необхідність перегляду поглядів на тектонічну еволюцію Землі викликана незадоволеністю сучасною іï парадигмою - тектонікою літосферних плит. Метою цієї статті $є$ здоровий критичний аналіз фундаментальних принципових дискусійних положень концепції тектоніки плит і гіпотези гарячих поясів Землі. Методика. Аналіз сутності гіпотези гарячих поясів Землі та концепції тектоніки плит, основних достоїнств і недоліків, що визначають їхні можливості. Хронологічний аналіз і кореляція геологічних структур Землі в зв'язку з просторовим розташуванням їхніх перетинань палеомагнітними екваторами, що відображають відповідні геотектонічні епізоди і катастрофічні події в еволюції Землі. Результати. Показана неспроможність базисної динамічної передумови тектоніки літосферних плит мантійної конвекції - через множинність (нестійкість) результатів іiі рішення. Як альтернативу розглянуто міграцію твердої оболонки планети по рідкофазній покрівлі зовнішнього ядра - нижня астеносфера - під впливом ротаційно-гравітаційного механізму. Водночас залишаються поза увагою конвекційне перемішування мантійної речовини і похідні від нього - субдукційне-обдукційне переміщення літосфери. Ротаційно-гравітаційний режим Землі, представляється основним механізмом структурної перебудови тектоносфери, який привів до формування на максимумах різновікових $\mathrm{i}$ різноспрямованих антіформ екваторіальних ротаційних рифтогенних здуттів планети. Наукова новизна. За ступенем самодостатності запропонована система поглядів на структурну еволюцію Землі представлена як відсутня ланки між антиподальними геологічними світоглядами: фиксизму, сформовані наукові канони якого залишилися недоторканними, і мобілізму, в новій його транскрипції на основі динамічного ротаційно-гравітаційного механізму $\mathrm{i}$ супроводжуючого глибинного суб'ядерного магматизму. Практична значущість. Перетин різновікових структур палеоекваторами зумовило формування в різних регіонах світу рифтогенних вузлів і їх аномальних об'єднань, в межах яких відомі найбільші промислові скупчення вуглеводнів. Аналіз рифтогенних вузлів як шляхів міграції глибинних флюїдів і зон розвантаження глибинної енергії дасть змогу нестандартно взятися за розроблення нової стратегії пошуку вуглеводневої сировини.

Ключові слова: тектоніка плит; гарячі пояси Землі; ротаційно-гравітаційний механізм; рифтогени; глибинний суб'ядерний магматизм. 


\section{KOBOLEV}

Subbotin Name Institute of Geophysics of NAS of Ukraine, 32, Palladin av., Kyiv, Ukraine, 03142, tel. +38(0442)4242152, e-mail kobol@igph.kiev.ua

\section{THE EARTH: VIRTUALITY OF PLATE TECTONICS, CONFORMALITY OF FIXISM AND MOBILISM}

Aim. The need to revise the views on the tectonic evolution of the Earth is caused by dissatisfaction with its modern paradigm - the tectonics of lithospheric plates. The purpose of this article is a healthy critical analysis of the fundamental principled discussion points of the concept of plate tectonics and the hypothesis of the hot belts of the Earth. Methodology: Analysis of the essence of the hypothesis of the hot belts of the Earth and the concept of plate tectonics, and discerning the main advantages and disadvantages that determine their capabilities. Chronological analysis and correlation of geological structures of the Earth have been made in connection with the spatial location of their intersecting paleomagnetic equators, reflecting corresponding geotectonic episodes, and catastrophic events in the evolution of the Earth. Results. Due to the multiplicity (instability) of the results of its solution, the inconsistency of the basic dynamic premise of the tectonics of lithospheric plate - mantle convection is shown. As an alternative, we considered the migration of the solid shell of the planet along the liquid-phase roof of the outer core and the lower asthenosphere being under the influence of a rotational-gravitational mechanism. Convection mixing of the mantle substance and the subduction-induced displacement of the lithosphere derived from it remain outside the discussion. The rotational-gravitational regime of the Earth appears to be the principle mechanism influencing the structural transformation of the tectonosphere, which led to the formation at maximums of different-aged and multidirectional antiforms of equatorial swells of the planet of rotational riftogens. Originality. In terms of the degree of self-sufficiency, the proposed hypothesis of the hot belts of the Earth is represented as a missing link between the antipodal geological worldviews: fixism, whose established scientific canons have remained inviolable, and mobilism in its new transcription, on the basis of dynamic rotational-gravitational mechanisms and the accompanying deep subnuclear magmatism. Practical significance. Crossing different age structures by paleoequators led to the formation of riftogenic nodes and their anomalous associations in various regions of the world, within which the largest industrial accumulations of hydrocarbons are known. The analysis of riftogenic nodes as outlets of migration of deep fluids and zones of unloading deep energy, will allow to unconventionally approach the development of a new strategy for the search for hydrocarbon raw materials.

Key words: plate tectonics; Hot belts of the Earth; Rotational-gravitational mechanism; Riftogen; Deep subnuclear magmatism.

\section{REFERENCES}

Anfilogov, V. N. Mantiynye plyumy: uroven' generatsii i mekhanizm peredachi energii k poverkhnosti Zemli [Mantle plumes: the level of generation and the mechanism of energy transfer to the Earth's surface] / V. N. Anfilogov, Yu. V. Khachay // Fundamental'nye problemy geotektoniki. Materialy XL tektonicheskogo soveshchaniya Tom I. [Fundamental problems of geotectonics. Materials of the XL Tectonic Meeting, Volume I] Moscow, GEOS, 2007, pp. 18-21.

Avsyuk Yu. N., Suvorova I. I. Fakticheskoe obosnovanie tsiklichnosti khoda prilivnoy evolyutsii sistemy ZemlyaLuna-Solntse [The actual substantiation of the cyclicity of the course of the tidal evolution of the EarthMoon-Sun system] // Fundamental'nye problemy geotektoniki. Materialy XL tektonicheskogo soveshchaniya Tom I. [Fundamental problems of geotectonics. Materials of the XL Tectonic Meeting, Volume I], Moscow, GEOS, 2007, pp. 3-6 (in Russian).

Belevtsev R. Ya., Blazhko V. I., Tereshchenko S. I. O termodinamicheskoy evolyutsii zemnoy kory $i$ tektonike plit [On the thermodynamic evolution of the earth's crust and plate tectonics], Geofizicheskiy zhurnal [Geophysical journal], 2016, 38, no. 6, pp. 118-136 (in Russian).

Belousov V. V. Osnovy geotektoniki [Fundamentals of geotectonics]. Moscow, Nedra Publ., 1989. 382 p. (in Russian).

Bugaevskiy G. N. Seysmicheskie issledovaniya neodnorodnosti mantii Zemli [Seismic studies of the heterogeneity of the earth's mantle]. Kiev, Naukova dumka Publ., 1978. 184 p. (in Russian).

Dapeng Zhao Seismic structure and origin of hotspots and mantle plumes. Earth and Planetary Letters, 2001, Vol. 192, p. 251-265.

Dobretsov N. L. Global'naya geodinamicheskaya evolyutsiya Zemli i global'nye geodinamicheskie modeli [Global geodynamic evolution of the Earth and global geodynamic models] // Geologiya i geofizika [Geology and geophysics]. 2010. 51, No. 6, pp. 761-784.

Dobretsov N. L., Kirdyashkin A. G., Kirdyashkin A. A. Glubinnaya geodinamika [Deep geodynamics]. Novosibirsk: Publishing house of the SB RAS, 2001. 409 p. 
Filat'yev V. P. Energetika tektoniki [Energy of tectonics] // Fundamental'nye problemy geotektoniki. Materialy XL tektonicheskogo soveshchaniya Tom I. [Fundamental problems of geotectonics. Materials of the XL Tectonic Meeting, Volume I], Moscow, GEOS, 2007, pp. 321-324 (in Russian).

Gordienko V. V. O gipoteze tektoniki plit [On the hypothesis of plate tectonics], Geofizicheskiy zhurnal [Geophysical journal]. - 2013, - 35, no. 6, pp. 72-101 (in Russian).

Gordienko V. V. Protsesu v tektonosfere Zemli (advektsionno-polimorfnay gipoteza [Processes in the Earth's tectonosphere (advection-polymorphic hypothesis)]. Saarbrücken: LAP, 2012, 256 p. (in Russian).

Grachev A. F. Mantiynye plyumy i problemy geodinamiki [Mantle plumes and problems of geodynamics] // Fizika Zemli. [Physics of the Earth], 2000, no. 4, pp. 3-37 (in Russian).

Grasby S. E., Sanei H., Beauchamp B. Catastrophic dispersion of coal fly ash into oceans during the latest Permian extinction // Nature Geoscience, 4, 2011, p. 104-107.

Grikurov G. E. Kontinental'nyy riftogeneza v domezozoyskoy evolyutsii zemnoy kory Antarktidy. Tektonicheskie protsessy [Continental rifting before Mesozoic evolution of the Earth's crust of Antarctica. In "Tectonic processes"]. Moscow, Nauka Publ., 1989, pp. 172-183 (in Russian)

Hart S. A large scale isotope anomaly in the Southern Hemisphere mantle. Nature, 1984, v. 309, no. 5971, p. 753-757.

Inoue H., Fuako Y., Tanabe K. et al. Whole mantle P-wave travel time tomography. Phys. Earth and Planet Iner., 1990, Vol. 59, p. 294-328.

Khain V. E., Bozhko N. A. Istoricheskaya geotektonika. Dokembriy [Historical geotectonics. Precambrian]. Moscow, Nedra Publ., 1988. 382 p. (in Russian).

Khazan Ya. M. Tektonika plit: " $z a$ " $i$ " $z a$ " [Tectonics of plates: "for" and "for"] Geofizicheskiy zhurnal [Geophysical journal]. 2014. - 36, no. 5, pp. 170-173 (in Russian).

Kobolev V. P., Orovetskiy Yu. P., Savenko B. Ya., Chulkov S. S., Burtnyy P. A., Karnaukhova E. E. Goryachie poyasa Zemli i Antarktandy (k probleme proiskhozhdeniya) [Hot belts of the Earth and the Antarcts (to the problem of origin)], Dopovidi NAN Ukrä̈i [Proceedings NAS of Ukraine], 2010, no.5, pp. 116-119 (in Russian).

Larson R. L., Olson P. Mantle plumes control magnetic reversal frequency. Earth and Plant. Sci. Lett., 1991, p. 437-447.

Lay T. The deep mantle thermo-chemical boundary: the putative mantle plume source // Geol. Soc. Amer. Spec. Paper 388. 2005, pp. 193-205

Litasov K. D., Shatskiy A. F. Sostav i stroenie yadra Zemli [Composition and structure of the Earth's core]. Novosibirsk, Publishing House of the SB RAS, 2016. 304 p. (in Russian).

Magnitskiy V. A. Vnutrennee stroenie $i$ fizika Zemli [Internal structure and physics of the Earth]. Moscow, Nauka Publ., 2006. 390 p. (in Russian)

Maryama S. Plum tectonic. J. Geol. Soc. Japan, 1994, v.100, no 1, p. 24-49.

Mikhaylova N. P., Kravchenko S. N., Glevasskaya A. M. Paleomagnetizm anortozitov [Paleomagnetism of anorthosites]. Kiev, Nauk. dumka Publ., 212 p. (in Russian).

Milanovskiy E. E. Riftovye zony kontinentov [Rift continental zones]. Moscow, Nauka Publ., 1976. 279 p. (in Russian)/

Orovetskiy Yu. P. Mantiynyy diapirizm [Mantle diapirism]. Kyiv, Naukova dumka Publ., 1990. 172 p. (in Russian).

Orovetskiy Yu. P., Kobolev V. P. Goryachie poyasa Zemli [Hot belts of the Earth]. Kyiv, Naukova dumka Publ., 2006. 312 p. (in Russian).

Orovetskiy Yu. P., Kobolev V. P. O retsenzii D. M. Pecherskogo na knigu Yu. P. Orovetskogo i V. P. Koboleva "Goryachie poyasa Zemli" [About the reviews D. M. Pechersky on the book Yu.P. Orovetsky and V.P. Kobolev "Hot belts of the Earth"] Geofizicheskiy zhurnal [Geophysical journal]. 2008m, 30, no. 4, pp. 163166 (in Russian).

Orovetsky Yu. P. Mantle plumes. Oxford \& IBH Publishing CO. PVT. LTD, New Delhi-Calcutta, 1999, 245 p.

Pavlenkova N. I. Empiricheskie osnovy rotatsionno-flyuidnoy gipotezy global'nogo tektogeneza [The empirical foundations of the rotational-fluid hypothesis of global tectogenesis] Geofizicheskiy zhurnal [Geophysical journal]. 2004. 26, no. 6, pp. 41-60 (in Russian).

Pavlenkova N. I. The Earth's degassing, rotation and expansion as sources of global tectonics. New Concepts in Global Tectonics Newsletter, 2012. no. 63, p. 31-53.

Pavlenkova N. I., Pavlenkova G. A. The upper mantle structure of the Northern Eurasia from the seismic profiling with nuclear explosions // New Concepts in Global Tectonics Journal, 2017, V. 5, No. 1, pp. 6-26.

Pecherskiy D. M. Retsenziya na knigu Yu. P. Orovetskogo i V. P. Koboleva «Goryachie poyasa Zemli [Review of the book Yu. P. Orovetsky and V. P. Kobolev "Hot belts of the Earth"] Geofizicheskiy zhurnal [Geophysical journal]. 2008. 30, no. 4, pp. 160-162 (in Russian).

Puspito N. T., Yamanaka Y., Miyatake T. Three-dimensional P-wave velocity structure beneath the Indonesian region. Tectonophysics, 1993, Vol. 220, pp. 175-192. 
Romanovskiy N. P. Tikhookeanskiy segment Zemli: glubinnoe stroenie, granitoidnye rudnye sistemy [Pacific segment of the Earth: deep structure, granitoid ore systems]. Khabarovsk, FEB RAS Publ., 1999, 166 p. (in Russian).

Shen Shu-zhong, Crowley James L., Wang Yue, Bowring Samuel A., Erwin Douglas H., Sadler Peter M., Cao Chang-qun, Rothman Daniel H., Henderson Charles M., Ramezani Jahandar, Zhang Hua, Shen Yanan, Wang Xiang-dong, Wang Wei, Mu Lin, Li, Wen-zhong, Tang Yue-gang, Liu Xiao-lei, Liu Lu-jun, Zeng Yong, Jiang Yao-fa, Jin Yu-gan. Calibrating the End-Permian Mass Extinction. Science, 2011. Vol. 334 no. 6061, p. $1367-1372$.

Sovetskiy entsiklopedicheskiy slovar' [Soviet encyclopedic dictionary], Moscow: Soviet Encyclopedia Publ., 1990, 1632 p. (in Russian).

Starostenko V. I., Geyko V. S., Kendzera A. V., Tsvetkova T. A, Bugaenko I. V., Verbitskiy S. T. Katastroficheskoe zemletryasenie 26 dekabrya 2004 g. u beregov Sumatry: prichiny, posledstviya $i$ uroki [A catastrophic earthquake on December 26, 2004 off the coast of Sumatra: causes, consequences and lessons]. Geofizicheskiy zhurnal [Geophysical journal]. 2005, 27, no. 6, pp. 949-961 (in Russian).

Storetvedt K. M. Geoscientific urban legends. New Concepts in Global Tectonics Journal, 2015. Vol. 3, no. 4, pp. 516-528.

Storetvedt, K. M. When global tectonics became a 'pathological science'. New Concepts in Global Tectonics Journal, 2014, Vol. 2, pp. 106-121.

Trubitsyn V. P. Reologiya mantii i tektonika okeanicheskikh litosfernykh plit [Rheology of the mantle and tectonics of oceanic lithospheric plates] Fizika Zemli, [Physics of the Earth], 2012, no. 6, pp. 3-22. (in Russian).

Trubitsyn V. P. Tektonika plavayushchikh kontinentov [Tectonics of the floating continents] Vestnik RAN [Bulletin RAS]. 2005., no.1, pp. 10-21 (in Russian).

Trukhalev A. I., Pogrebitskiy Yu. E., Belyatskiy B. V. Drevnie porody so Sredinno-Atlanticheskogo khrebta [Ancient rocks from the Mid-Atlantic Ridge]. Otechestvennaya geologiya [Domestic Geology]. 1993, 11, pp. 81-89 (in Russian).

Tuezov I. K. Karta teplovogo potoka Tikhogo okeana i prilegayushchikh kontinentov: (poyasnitel'naya zapiska) [Map of the heat flow of the Pacific and adjacent continents: (explanatory note)]. Khabarovsk, FEB RAS Publ., 1988, 33 p. (in Russian).

Tyapkin K. F. Obshchnost' $i$ otlichie geologicheskikh razrezov tektonosfery Zemli v predelakh kontinentov $i$ okeanov [The generality and difference of geological sections of the Earth's tectonosphere within continents and oceans]. Geologiya i poleznye iskopaemye mirovogo okeana [Geology and Minerals of the World Ocean], 2012, 1 (27), pp. 22-33 (in Russian).

Tyapkin K. F. Otsenka novoy rotatsionnoy gipotezy strukturoobrazovaniya $v$ tektonosfere Zemli s pozitsiy dialekticheskogo materializma [Evaluation of a new rotational hypothesis of the structure formation in the Earth's tectonosphere from the standpoint of dialectical materialism]. Naukoviy visnik NGU [Scientific Bulletin NMU]. 2013, no. 1, pp. 11-24 (in Russian).

Tyapkin K. F., Dovbnich M. M. Novaya rotatsionnaya gipoteza strukturoobrazovaniya $i$ ee geologomatematicheskoe obosnovanie [New rotational hypothesis of structure formation and its geological and mathematical justification]. Donetsk, Noulidzh Publ., 2009, 342 p. (in Russian).

Vinogradov L. A., Kudryavtsev V. N. Rotatsionnaya gorizontal'naya sostavlyayushchaya izostazii [Rotational horizontal component of isostasy]. Apatity, Preprint of the Geological Institute of the Kola Branch of the USSR Academy of Sciences, 1987, 48 p. (in Russian).

Надійшла 26.08.2017 p. 